\title{
DIRECT LIQUEFACTION PROOF-OF-CONCEPT PROGRAM
}

Hydrocarbon Technologies Inc., Lawrenceville, $N J$

A. G. Comolli

T. L. K. Lee

J. Hu

G. Popper

M. D. Elwell

J. Miller

D. Parfitt

P. Zhou

Topical Report

Bench Run 09 (227-106)

Work Performed Under Contract No. DE-AC22-92PC92148

For

U.S. Department of Energy

Federal Energy Technology Center

By

Hydrocarbon Technologies Inc., Lawrenceville, NJ

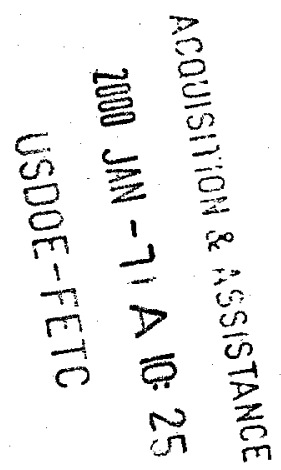

December 1999 


\section{DISCLAIMER}

Portions of this document may be illegible in electronic image products. Images are produced from the best available original document. 


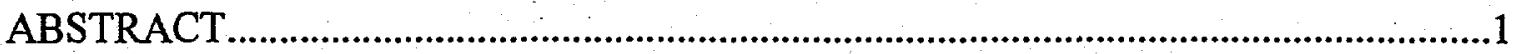

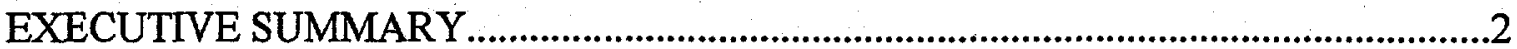

BACKGROUND, OBJECTIVES, AND SCOPE OF WORK …........................................

EXPERIMENTAL

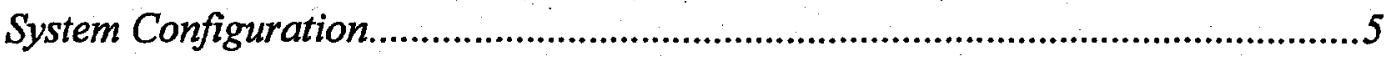

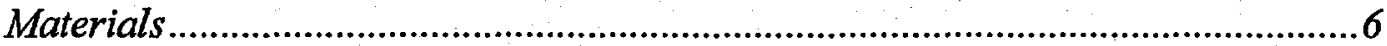

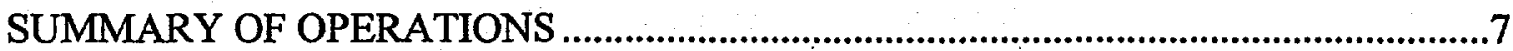

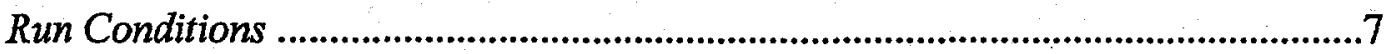

Startup \& Condition 1 ............................................................................................

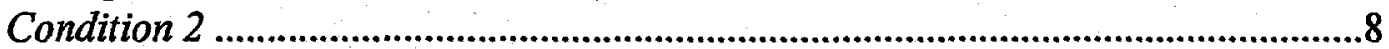

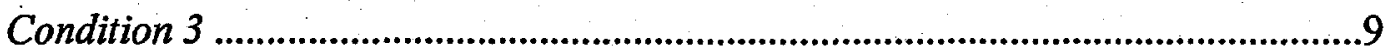

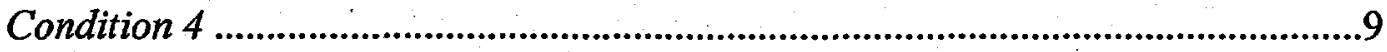

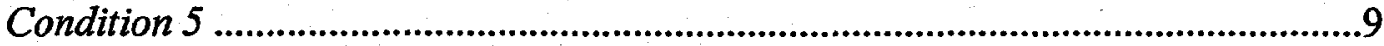

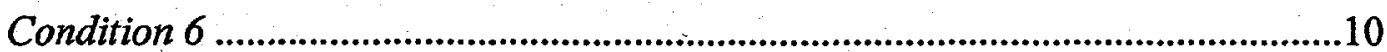

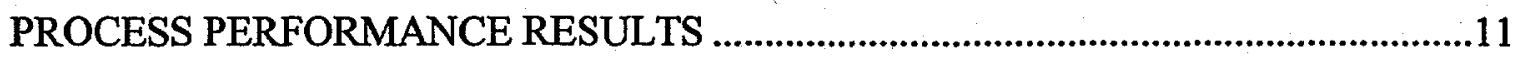

Coal and $524^{\circ} \mathrm{C}^{+}$Residuum Conversion............................................................11

$C_{4}-524^{\circ} \mathrm{C}$ Distillate and $524^{\circ} \mathrm{C}^{+}$Residuum Yield ..............................................11

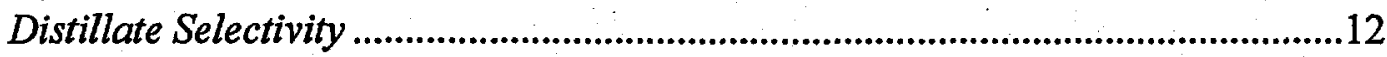

Hydrogen Consumption and Light Gas $\left(C_{1}-C_{3}\right)$ Yield ............................................12

Hydrogen Utilization .................................................................................................13

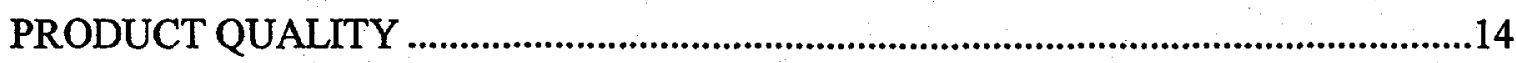

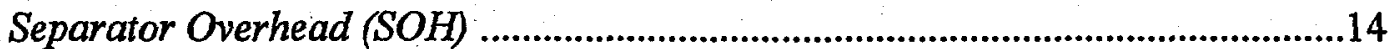

Vacuum Separator Overhead (VSOH) ...........................................................14

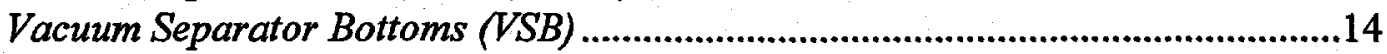

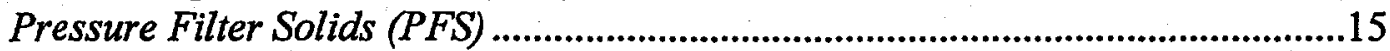

Characterization of Total Distillate Product ...............................................................15

DISCUSSION OF PROCESS PERFORMANCE RESULTS.........................................16

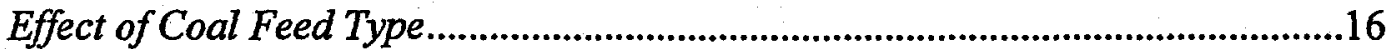

Effect of GelCat Formulation and Loading .............................................................16

Operational Parameters ..........................................................................................17

TECHNO-ECONOMIC ASSESSMENT .................................................................18

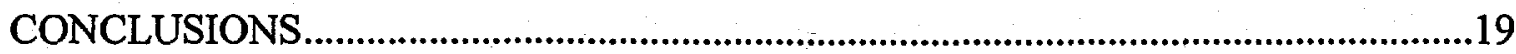




\section{LIST OF TABLES}

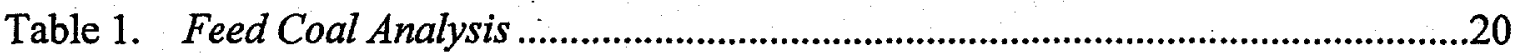

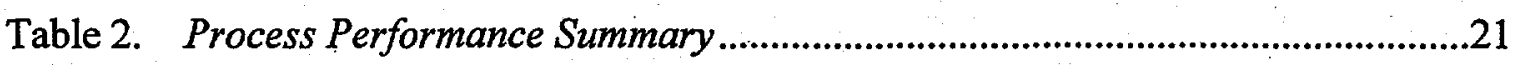

Table 3. Separator Overhead (SOH) Properties................................................................22

Table 4. Vacuum Still Overheads (VSOH) Properties ......................................................23

Table 5. Vacuum Still Bottoms (VSB) Properties .............................................................24

Table 6. Pressure Filter Solids (PFS) Properties ............................................................25

Table 7. Characterization of Total Distillate Product for Condition 1 ............................26

Table 8. Characterization of Total Distillate Product for Condition 2 ...........................27

Table 9. Material Balance for Technical Assessment ....................................................28

Table 10. Hydrogen Balance, Utilities \& Thermal Efficiency ..........................................29

Table 11. Capacities of Process Units \& Off-sites .............................................................30

Table 12. Liquefaction Plant Investment Details.............................................................31

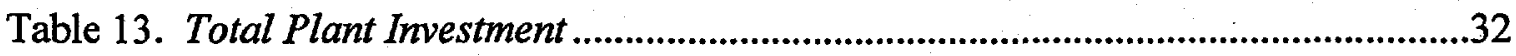

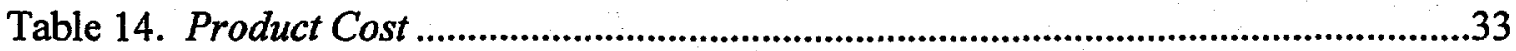

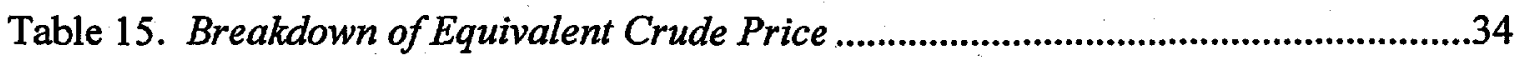




\section{LIST OF FIGURES}

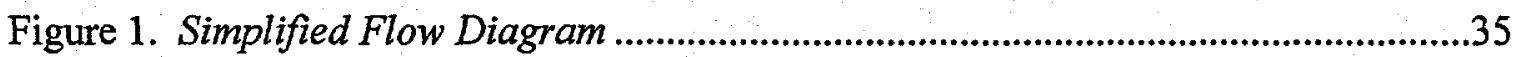

Figure 2. Daily Operating Conditions ….......................................................................36

Figure 3. Daily Material Balance .................................................................................37

Figure 4. Coal and Residuum Conversion ....................................................................38

Figure 5. Distillate and Residuum Yield ...........................................................................39

Figure 6. Distillate Fraction Yield .................................................................................40

Figure 7. Hydrogen Consumption and Light Gas Yield.................................................41

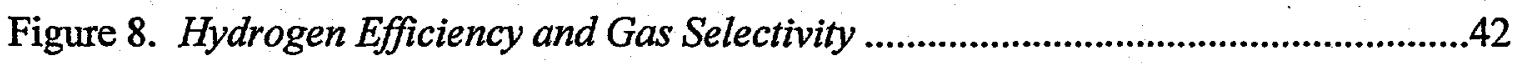

Figure 9. Coal Type and Feed Conversion .......................................................................43

Figure 10. Coal and Product Yields..........................................................................44

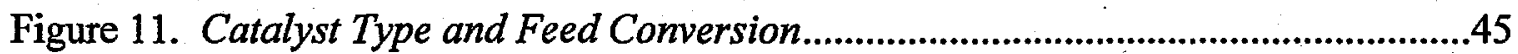

Figure 12. Catalyst Type and Product Yields ..................................................................46

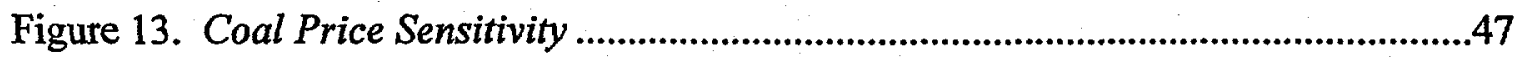

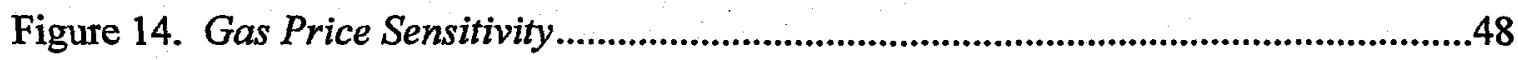




\begin{abstract}
This report presents the results of the bench-scale work, Bench Run PB-09, HTI Run Number 227-106, conducted under the DOE Proof-of-Concept Option Program in direct coal liquefaction at Hydrocarbon Technologies Inc. in Lawrenceville, New Jersey. Bench Run PB-09 was conducted using two types of Chinese coal, Shenhua \#2 and Shenhua \#3, and had several goals. One goal was to study the liquefaction performance of Shenhua \#2 and Shenhua \#3 with respect to coal conversion and distillate production. Another goal of Bench Run PB-09 was to study the effect of different GelCat ${ }^{\mathrm{T}}$ formulations and loadings. At the same time, the space velocity and the temperature of the first reactor, $K-1$, were varied to optimize the liquefaction of the two Chinese coals.

The promoter-modified HTI GelCat ${ }^{\mathrm{TM}}$ catalyst was very effective in the direct liquefaction of coal with nearly $92 \%$ maf coal conversion with Shenhua \#3 and $93 \%$ maf coal conversion with Shenhua \#2. Distillate yields $\left(\mathrm{C}_{4}-524^{\circ} \mathrm{C}\right)$ varied from $52-68 \%$ maf for Shenhua \#3 coal to 54$63 \%$ maf for Shenhua \#2 coal. The primary conclusion from Bench Run PB-09 is that Shenhua \#3 coal is superior to Shenhua \#2 coal in direct liquefaction due to its greater distillate production, although coal conversion is slightly lower and $\mathrm{C}_{1}-\mathrm{C}_{3}$ light gas production is higher for Shenhua \#3. The new promoter modified GelCat ${ }^{\mathrm{TM}}$ proved successful in converting the two Chinese coals and, under some conditions, producing good distillate yields for a coal-only bench run. Run PB-09 demonstrated significantly better performance of China Shenhua coal using HTI's coal direct liquefaction technology and GelCat ${ }^{\mathrm{TM}}$ catalyst than that obtained at China Coal Research Institute (CCRI, coal conversion $88 \%$ and distillate yield $61 \%$ ).
\end{abstract}




\section{EXECUTIVE SUMMARY}

Bench Run PB-09 is part of the Proof-of-Concept Bench Option Contract between the United States Department of Energy and Hydrocarbon Technologies, Inc. (HTI). The primary goal of the run was to evaluate the direct liquefaction of two Chinese coals, Shenhua \#2 and Shenhua \#3; and to compare them with earlier data on the direct liquefaction of other coals. A further goal of the run was to evaluate a new promoter-modified GelCat ${ }^{\mathrm{TM}}$ at different loadings.

The entire bench run was conducted over thirty days and was divided into six operating conditions. PB-09 was initially scheduled to be a twenty-six day long operation, but was increased to thirty days in an attempt to increase the distillate yields. Shenhua coal \#3 was used in conditions one through four, while Shenhua \#2 coal was used in the final two conditions. A modified GelCat ${ }^{\mathrm{TM}}$ was used throughout the run at varying catalyst flow rates. All six conditions used a GelCat ${ }^{\mathrm{TM}}$ with a $\mathrm{Fe} /$ Promoter atomic ratio of $100 / 4$, except period two, at a ratio of 100/2.

The following points were the highlights of bench run PB-09.

- The promoter-modified GelCat ${ }^{\mathrm{TM}}$ catalyst was effective in the direct liquefaction of both Chinese coals. Coal conversion, on a moisture and ash-free (maf) basis, was almost $92 \%$ with Shenhua \#3 coal and $93 \%$ with Shenhua $\# 2$ coal.

- The $\mathrm{C}_{4}-524^{\circ} \mathrm{C}$ distillate yield with Shenhua \#3 coal varied from 52 to $68 \%$ maf, and 53 to $64 \%$ maf with Shenhua $\# 2$ coal. The $524^{\circ} \mathrm{C}^{+}$residuum conversion varied from 70 to $84 \%$ maf with Shenhua \#3 coal and 71 to $80 \%$ maf with Shenhua $\# 2$ coal.

- The $\mathrm{C}_{1}-\mathrm{C}_{3}$ light gas yield was slightly higher with Shenhua \#3 coal than with Shenhua \#2 coal ( $13 \%$ vs. $12 \%$ maf, respectively).

- The $524^{\circ} \mathrm{C}$ residuum yield was lower for Shenhua $\# 3$ coal, $7 \%$ maf, than for Shenhua $\# 2$ coal, $13 \%$ maf.

- Overall, both coals had superior direct liquefaction performance, and Shenhua \#3 was better than Shenhua \#2 coal under the process conditions in PB-09, as shown by the higher distillate yields, with only slightly higher $\mathrm{C}_{1}-\mathrm{C}_{3}$ light gas yields and slightly lower coal conversion.

- The promoter-modified GelCat ${ }^{\mathrm{TM}}$ with a Fe/Promoter composition of 100/4 (L-942) was superior to the analogous catalyst with a ratio of $100 / 2$ (L-943), as evidenced by product yields. Upon changing from L-942 to L-943 the $\mathrm{C}_{4}-524^{\circ} \mathrm{C}$ distillate yield derived from Shenhua \#3 decreased from $68 \%$ maf to $66 \%$ maf, the $524^{\circ} \mathrm{C}^{+}$residuum conversion decreased form $84 \%$ maf to $82 \%$ maf, the $\mathrm{C}_{1}-\mathrm{C}_{3}$ light gas yields increased form $12 \%$ maf to $13 \%$ maf, and the $524^{\circ} \mathrm{C}^{+}$residuum yield increased form $7 \%$ maf to $9 \%$ maf, while the coal conversion stayed the same at $91 \%$ maf. 


\section{BACKGROUND, OBJECTIVES, AND SCOPE OF WORK}

The POC Bench Option Project (PB-Series) was started in order to study a wide variety of coal liquefaction and co-processing conditions using various plastics, waste oils, auto shredder material, petroleum residual oils, and lignin-cellulose material. The data collected would be used to develop a continuous multistage liquefaction process using a variety of feeds. Another key concept in the PB-Series runs is the development and testing of a catalytic system that has a high conversion of coal and other feeds with high distillate yields and low $\mathrm{C}_{1}-\mathrm{C}_{3}$ gas yields. PB-09 was carried out over thirty days using six process conditions. Two Chinese coals were used in an all-dispersed catalyst mode using promoter-modified GelCat ${ }^{\mathrm{TM}}$ with different elemental compositions and under different operating parameters, with the ultimate goal of using data derived from PB-09 in producing economic comparisons with other runs in the DOE database and designing larger scale liquefaction processes to be used in China using one, or both, of these coals.

\section{Objectives}

The main objectives of PB-09 were:

To study the direct liquefaction of two Chinese coals using HTI's modified GelCat ${ }^{\mathrm{TM}}$ catalyst and bench unit in an all-dispersed catalyst mode using extinction recycle solvent conditions.

To study the activity of different dispersed catalytic systems and conditions using HTI's modified GelCat ${ }^{\mathrm{TM}}$.

To achieve coal conversion greater than $90 \%$, maximize distillate yield and minimize gas yield. 


\section{EXPERIMENTAL}

\section{System Configuration}

The direct liquefaction test of the two Shenhua coal samples was carried out in two 2-liter reactors separated by an interstage separator and with an in-line hydrotreater, shown simplified in Figure 1.

The premixed slurry of coal, heated recycle oil and catalyst is charged to the Feed Tank (P-2) every two hours. The feed is pumped and preheated to about 315 to $371^{\circ} \mathrm{C}$, depending on the viscosity. Before entering the first-stage reactor $(\mathrm{K}-1)$, the heated feed is joined with hydrogen and hydrogen sulfide. The effluent from $\mathrm{K}-1$ is separated in the hot separator (O-1A) into a liquid slurry stream which is fed to the second-stage reactor (K-2), and a vapor which is sent to cold separator (O-2A). From O-2A, the vapor is cooled and condensed, via the Overhead Receiver (O$7 \mathrm{~A})$, the Vent Gas Knock Out (O-4A), and the Flare Knock Out (O-5A). Condensates from these vessels are sent to the Hydrotreater Unit (K-3). Gases are vented.

The second-stage reactor feed is joined with hydrogen and TNPS (di-tertiary-nonyl polysulfide). The effluent is sent to the second-stage Hot Separator (O-1). The overhead vapor from O-1 goes to the Hydrotreater Unit $(\mathrm{K}-3)$ along with the first-stage liquids previously mentioned. The effluent from K-3 is sent to the Cold Separator (O-2). After going though the Overhead Receiver $(\mathrm{O}-7)$, the Vent Gas Knock Out (O-4), and the Flare Knock Out (O-22), the hydrotreater effluent is separated into the separator overhead product, vent gas, and knockouts. The knockouts are returned to $\mathrm{K}-3$ for further processing.

The bottoms from the Hot Separator (O-1) are sent to the Flash Vessel (O-3), the Overhead Receiver (O-17), and the Bottoms Receiver (O-6). In $0-6$, this stream is separated into the separator bottoms, knock outs (also sent back to the hydrotreater unit), and the bottoms vent gas. Water is added to the feed line of the cold separators $0-2$ and O-2A.

The products from the operations shown in Figure 1 are three gases (O-5A, O-22 and 0-14), separator overhead (O-7), and 0-6 bottoms. Not shown in Figure 1 are three downstream batch processing steps: pressure filtration, vacuum distillation and extraction. Pressure filtration separates the 0-6 bottoms into a Pressure Filter Liquid (PFL) and a Pressure Filter Cake (PFC). Vacuum distillation, at a nominal $454^{\circ} \mathrm{C}$ cut point, separates the PFL into Vacuum Still Bottoms (VSB) and Vacuum Still Overhead (VSOH). Finally the PFC is extracted with toluene to recover toluene-soluble oils from toluene-insoluble solid.

\section{Materials}

Two coals were received from China, designated Shenhua Coal \#2 (HTI-6769) and Shenhua Coal \#3 (HTI-6770). Table 1 shows the properties of the two coal samples, as analyzed by HTI. 
Three iron-based catalysts of different formulations with two promoters were prepared for the run, using proprietary procedures. These catalysts were designated L-942, L-943, and L-945. L942 and L-945 had similar promoters content (Fe/Promoter atomic ratio of 100/4) which was higher than that of L-943 (100/2).

The Hydrotreater used Criterion C-411 Trilobe catalyst. 


\section{SUMMARY OF OPERATIONS}

PB-09 was operated over a thirty-day time span (30 operating periods each 24 hours long) and included six different conditions which was four days longer and one condition more than originally scheduled. Shenhua \#3 coal was used in conditions 1 through 4 and Shenhua \#2 coal was used in conditions 5 and 6 . The L-943 catalyst was used in condition 2, while the other five conditions used either L-942 or L-945. Other variables were feed space velocity, catalyst flow rate and $\mathrm{K}-1$ temperature. The $\mathrm{K}-2$ temperature was kept at $450^{\circ} \mathrm{C}$, the in-line hydrotreater temperature was $379^{\circ} \mathrm{C}$, and the $0-1 \mathrm{~A}$ hot separator temperature was $343^{\circ} \mathrm{C}$ throughout the entire run.

Operating parameters in condition 1 were based on previous experience with Shenhua coal, which was obtained at CCRI and HTI. Conditions 2 and 3 studied the impact of catalyst loading and promoter levels. In condition 4 , space velocity was increased by $20 \%$ to assess its impact. In condition 5 , the first-stage reactor temperature was lowered by $5^{\circ} \mathrm{C}$, in an attempt to reduce the gas yield. Finally, in condition 6 operating parameters were the same as in condition 1, with Shenhua \#2 coal.

Operation of the unit during the run was very smooth. Feed was continuously maintained to the unit for 713 hours (just short of thirty days), except for two minor interruptions totaling four hours. In the first interruption, during Period 5 , the first-stage backpressure control valve plugged, necessitating about a three-hour oil wash at lower reactor temperature. In the second instance during Period 25, a problem with the charge pump packing caused feed to be interrupted for about one hour. The run was voluntarily terminated after the completion of Period 29, as scheduled. The unit was found clean upon inspection after shutdown, except for a plug in the recycle line of the first-stage reactor.

The average daily material balance for this run was $98.4 \mathrm{~W} \%$. A chart of the daily material balance is shown in Figure 2. Table 2 shows the Operating Summary and the Process Performance for the run, while Figure 3 shows the reactor temperatures and feed space velocity for each period. The operational problems mentioned above are evident in Figures 2 and 3 . The K-1 temperature dip in Periods 16 and 17 were a response to the increased velocity specified in the run plan.

\section{Run Conditions}

PB-09 (227-106) included six different conditions. Shenhua \#3 coal was used in conditions 1 through 4 and Shenhua \#2 coal was used in conditions 5 and 6 . The low promoter-level GelCat ${ }^{\mathrm{TM}}$, L-943, was used in condition 2, but in the other five conditions either L-942 or L-945 was used, both having the same composition. Other variables were feed space velocity, catalyst flow rate, and $\mathrm{K}-1$ temperature. The $\mathrm{K}-2$ temperature was kept at $450^{\circ} \mathrm{C}$, the in-line hydrotreater 
temperature was kept at $379^{\circ} \mathrm{C}$, and the $0-1 \mathrm{~A}$ hot separator temperature was kept at $343^{\circ} \mathrm{C}$ throughout the entire run.

\section{Startup \& Condition 1 (periods 1-5)}

Startup consisted of insulating the unit, establishing the proper flow of oils and gases, setting the correct temperatures, pressurizing the system, and adding the catalyst to the HTU. Filtered heavy gas oil was used as the startup oil. Period 1 started with the introduction of coal feed at 0400 hours on October 15, 1997. Each twenty-four-hour period started and ended at 0400 hours. During condition 1 the Shenhua \#3 coal feed rate was $1069 \mathrm{~g} / \mathrm{h}$, the $0-6$ bottoms feed rate was $960 \mathrm{~g} / \mathrm{h}$, and both the VSB and the toluene-extracted oil (TEO) feed rates were $240 \mathrm{~g} / \mathrm{h}$. the reactor feed space velocity was $449 \mathrm{~kg} / \mathrm{h} / \mathrm{m}^{3}$. The reactor temperatures were $440^{\circ} \mathrm{C}$ in $\mathrm{K}-1$ and $450^{\circ} \mathrm{C}$ in K-2. The promoter-modified GelCat ${ }^{\mathrm{TM}}$ catalyst (1-942) was fed at the relatively low rate of $54 \mathrm{~g} / \mathrm{h}$.

In Period 2 the vacuum still cut point was increased from $427^{\circ} \mathrm{C}$ to $454^{\circ} \mathrm{C}$ and the $\mathrm{O}-1$ temperature was increased to $357^{\circ} \mathrm{C}$ from $343^{\circ} \mathrm{C}$ in an attempted residual oil extinction recycle. There was a feed interruption during period 5-A when the backpressure control valve plugged. The unit was put on wash for 4 hours. All gases were routed through the second stage vent, the temperature was lowered and all water, $\mathrm{H}_{2} \mathrm{~S}$, and TNPS injections were halted. The plug broke on its own, but the feed interruption necessitated the use of period 4 as the work-up for condition 1.

\section{Condition 2 (periods 6-10)}

In period 7-A the overhead line became plugged and acetic acid (1\%) was added to the water injection rate of $300 \mathrm{~g} / \mathrm{h}$, to dissolve the ammonium sulfide salt. Near the end of period 7-B excess VSOH was added to $\mathrm{P}-2$ to decrease the viscosity, which had been slowly increasing. The VSOH additions were stopped in period 8-A and the VSB additions were increased to $480 \mathrm{~g} / \mathrm{h}$ to make up for the loss of TEO in the feed. Starting in period 9 the TEO feed rate was $100 \mathrm{~g} / \mathrm{h}$, VSB feed rate was $290 \mathrm{~g} / \mathrm{h}$, and the $0-6$ bottoms flow rate was $1050 \mathrm{~g} / \mathrm{h}$. period 10 was the work up period for condition 2 .

Condition 2 differed from the first condition only in that the GelCat ${ }^{\mathrm{TM}}$ catalyst (L-943) had a lower loading of promoter. There was a concurrent increase in the catalyst flow rate to $71 \mathrm{~g} / \mathrm{h}$ during period 8 with a further increase to $95 \mathrm{~g} / \mathrm{h}$ for periods 9 and 10 . Coal and oil feed rates, along with all temperatures and pressures, were the same as in Condition 1.

\section{Condition 3 (periods 11-15)}

Condition 3 returned to the original catalyst (L-942) and the catalyst flow rate was lowered to 80 $\mathrm{g} / \mathrm{h}$. periods 11 through 13 saw an increase in the VSB and O-6 bottoms feed rates to $390 \mathrm{~g} / \mathrm{h}$ and 
$1050 \mathrm{~g} / \mathrm{h}$, respectively, as TEO was removed. TEO was added back to the feed in periods 14 and 15 with a feed rate of $100 \mathrm{~g} / \mathrm{h}$ and the VSB feed rate was decreased to $290 \mathrm{~g} / \mathrm{h}$.

There was a sudden increase in viscosity during period 13-A, possibly due to a piece of semi-dry material in the charge can that was added to P-2. Period 15 was the work up period for condition 3.

\section{Condition 4 (periods 16-19)}

Operating parameters in this condition 4 were set so as to reduce the gas yield. Starting with period 16-A, the space velocity was increased $20 \%$. The feed rate of Shenhua \#3 coal and O-6 bottoms increased to $1283 \mathrm{~g} / \mathrm{h}$ and $1260 \mathrm{~g} / \mathrm{h}$, respectively. The TEO was completely removed from the feed slurry for the rest of the run while the VSB feed rate was increased to $468 \mathrm{~g} / \mathrm{h}$. the GelCat $^{\mathrm{TM}}$ (L-942) catalyst flow rate was increased to $96 \mathrm{~g} / \mathrm{h}$. a new catalyst, L-945, that had the same elemental composition as L-942 was introduced in period $17-A$ with a flow rate of $113 \mathrm{~g} / \mathrm{h}$. due to decreased distillate formation, the K-1 temperature was raised to $440^{\circ} \mathrm{C}$ in period 17 . Period 19 was the work up period for condition 4.

\section{Condition 5 (periods 20-23)}

Shenhua \#2 coal was introduced to the reactor at the beginning of Condition 5 , at a rate of 1069 $\mathrm{g} / \mathrm{h}$ as the space velocity was reduced back to $455 \mathrm{~kg} / \mathrm{h} / \mathrm{m}^{3}$. The $0-6$ bottoms and VSB feed rates were decreased at the same time to $1050 \mathrm{~g} / \mathrm{h}$ and $390 \mathrm{~g} / \mathrm{h}$, respectively. The L-945 catalyst flow rate was lowered to $93 \mathrm{~g} / \mathrm{h}$. the K-1 temperature was also decreased at the beginning of period 20 to $435^{\circ} \mathrm{C}$ in another attempt to lower the gas yield. PFL, which had been used as the buffer oil, was replaced with a mixture of VSOH and PFL in the ratio of 1:3, in period 21-B. the K-1 buffer line plugged in period 22, and therefore the $\mathrm{H}_{2}$ pressure in $\mathrm{K}-1$ was increased by $10 \%$ in period 23. Period 23 is the work up period for condition 5. 


\section{Condition 6 (periods 24-29)}

The goal of the last condition was to increase distillate yield while minimizing the light gas yield. Condition 6 used the same catalyst loading, space velocity, feed rates, $0-6$ bottoms rate, VSB rate and L-945 catalyst, for Shenhua \#2 coal as in Condition 1 with Shenhua \#3 coal. The K-1 temperature was increased to $440^{\circ} \mathrm{C}$ in period 24-A (taking 2 hours to reach the new temperature) and was further increased to $443^{\circ} \mathrm{C}$ in period $24-\mathrm{B}$, again taking 2 hours to reach the final temperature. The $0-6$ bottoms flow rate was reduced to $858 \mathrm{~g} / \mathrm{h}$ starting in period 24 . The hot separator (O-1A) temperature was increased to $399^{\circ} \mathrm{C}$ (originally $343^{\circ} \mathrm{C}$ ) in period 24-A.

There was an interruption in the feed pumping in period 25-B due to problems with the charge pumps. The unit was put on heavy oil wash for less than one hour, until the problem was rectified. The feed pump problem necessitated an extension of condition 6 . A new feed blend in period 26-A consisted of $1069 \mathrm{~g} / \mathrm{h}$ of Shenhua $\# 2 \mathrm{coal}, 720 \mathrm{~g} / \mathrm{h}$ of O- 6 bottoms, $720 \mathrm{~g} / \mathrm{h}$ of VSB and $62 \mathrm{~g} / \mathrm{h}$ of L-945. The vacuum cut point was raised from $427^{\circ} \mathrm{C}$ to $454^{\circ} \mathrm{C}$ and higher during period 28 and the VSB flow rate was raised in period $29-\mathrm{A}$ from $720 \mathrm{~g} / \mathrm{h}$ to $820 \mathrm{~g} / \mathrm{h}$ in order to recycle the VSB to extinction. Period 29 was the work up period for condition 6. 


\section{Process Performance Results}

A discussion on the feed conversion and of the yields of different products follows. The overall process performance is summarized in Table 2 and is depicted in Figures 4 through 7 . The data presented in these tables and figures represent the performance during the last period in each condition, after steady-state operation had presumably been achieved for that condition.

\section{Coal and $524^{\circ} \mathrm{C}^{+}$Residuum Conversions}

Coal and $524^{\circ} \mathrm{C}^{+}$residuum conversions obtained for each condition are shown in Figure 4. Coal conversion is defined as the conversion to quinoline-soluble products, and is calculated on an $\mathrm{SO}_{3}{ }^{-}$free basis. Coal conversion for the entire run varied from 90 to $93 \%$ on a moisture-and-ashfree (maf) basis, with an average of about $91 \%$. Overall, there is no significant difference in coal conversion between the two Chinese coals. Shenhua \#2 coal (operating conditions 5 and 6 ) had coal conversions of 90.5 and $93.1 \%$ maf, while Shenhua \#3 coal (operation conditions 1 through 4) had conversion in the range of 90 to $91.8 \%$. There is, however, a large variation in the $524^{\circ} \mathrm{C}^{+}$ residuum conversion, varying from 69 to $84 \% \mathrm{maf}$, as seen in Figure 4 . The highest conversion occurs in condition 1, while the lowest occurs in condition 4 (highest space velocity) both with Shenhua \#3 coal. The exact process conditions (reactor temperatures, space velocity, catalyst composition and loading), rather than the type of coal, exerted the most influence on the overall $524^{\circ} \mathrm{C}^{+}$residuum conversion.

\section{$\mathrm{C}_{4}-524^{\circ} \mathrm{C}$ Distillate and $524^{\circ} \mathrm{C}^{+}$Residuum Yields}

The $\mathrm{C}_{4}-524^{\circ} \mathrm{C}$ distillate and $524^{\circ} \mathrm{C}^{+}$residuum yields are shown in Figure 5. Distillate yields over the run varied from 52 to $68 \%$ maf and $524^{\circ} \mathrm{C}^{+}$residuum yields varied from 7 to $22 \%$ maf. With Shenhua \#3 coal (condition 1 through condition 4), the distillate yield decreased form 68 to $52 \%$ maf, while the $524^{\circ} \mathrm{C}^{+}$residuum increased from 7 to $22 \%$ maf. The distillate yield with Shenhua $\# 2$ coal (conditions 5 and 6 ), was 54 and $63 \%$ maf, while the respective $524^{\circ} \mathrm{C}^{+}$residuum yields were 20 and $13 \%$ maf. As shown in Figure 5, there is an inverse relationship between $\mathrm{C}_{4}-524^{\circ} \mathrm{C}$ distillate and $524^{\circ} \mathrm{C}^{+}$residuum yields.

The distillate yield in condition 1 was $68 \%$ maf. In condition 2 , the Fe catalyst loading was increased 50 percent, but the promoters were reduced by $25 \%$, compared to condition 1 . The light naphtha yield increased by $2 \mathrm{wt}$ \% and the dry gas yield increased slightly at the expense of heavier liquid products, but the total $\mathrm{C}_{4}-524^{\circ} \mathrm{C}$ distillate yield dropped by $3 \mathrm{w} \%$, to $65 \mathrm{w} \%$. condition 3 used the same Fe loading as in condition 2, but both catalyst promoters were doubled. This resulted in a further slight increase in light products (dry gas and naphtha), but a further reduction in total distillate yield, to $59 \mathrm{w} \%$. In condition 4 , the space velocity was increased by $20 \%$ over previous conditions, in an attempt to reduce the $C_{1}-C_{3}$ gases yield. A drastic decrease in distillate yield, to $52 \mathrm{w} \%$ was observed. When coal was switched (\#3 to \#2) in 
Condition 5 , the first-stage reactor temperature was lowered, while the space velocity was reduced to the previous level. Apparently the lower $\left(5^{\circ} \mathrm{C}\right)$ temperature produced the same result as increased space velocity, and resulted in a total distillate yield of $54 \mathrm{w} \%$. Operating parameters in condition 6 were nearly the same as in condition 1, with slightly higher space velocity and slightly higher first-stage reactor temperature. The distillate yield was found to increase to 63 $\mathrm{w} \%$, a few percentage points lower than in condition 1, possibly due to performance differences in the two coals. There was a change in recycle strategy in this last condition, namely to recycle as much resid as possible. This resulted in a recycle containing $64 \mathrm{w} \%$ resid, compared to $49-59$ $\mathrm{w} \%$ in previous conditions. Due to the complexity of the parameter matrix, the effect of recycle composition is not yet conclusive.

\section{Distillate Selectivity}

The selectivity of each distillate fraction, namely naphtha (IBP- $177^{\circ} \mathrm{C}$ ), middle distillate (177$343^{\circ} \mathrm{C}$ ), and heavy distillate $\left(343-524^{\circ} \mathrm{C}\right.$ ) is shown in Figure 6. As discussed in the previous section, the increased catalyst usage in conditions 2 and 3 enhanced the light-ends distribution and correspondingly reduced the relative portion of the heavier distillates. Despite use of different coal types and despite variations in space velocity and first-stage reactor temperature, the liquid products obtained in conditions 4 and 5 showed the same trend of low total distillate yield with high yields of middle and heavy distillates. Liquid products from condition 6 showed high selectivity to heavy-distillate formation. This difference in performance, compared to condition 1, may be partly attributable to the differences in properties of the two coal samples and partly to the difference in the recycle composition.

\section{Hydrogen Consumption and Light Gas $\left(C_{1}-C_{3}\right)$ Yield}

As shown in Figure 7, the hydrogen consumption for conditions 1 through 4 (Shenhua \#3 coal) decreased from 8.8 to $6.8 \%$ maf, varying with the amount of $\mathrm{C}_{4}-524^{\circ} \mathrm{C}$ distillate produced. The final two conditions (Shenhua \#2 coal) had a hydrogen consumption of $7.1-7.3 \%$ maf. The $\mathrm{C}_{1-}$ $\mathrm{C}_{3}$ light gas yield for the first four conditions using Shenhua \#3 coal is $12-13 \%$, slightly higher than that in Conditions 5 and 6 using Shenhua $\# 2$ coal (about $11 \%$ maf). The relatively low space velocities, coupled with the chemical nature of the two coal samples, probably contributed to the relatively high gas yields produced by \#3 coal in conditions 1 to 3 .

\section{Hydrogen Utilization}

There are two major indicators that characterize hydrogen utilization: hydrogen efficiency and $\mathrm{C}_{1}-\mathrm{C}_{3}$ gas selectivity. Hydrogen efficiency is the amount of distillate produced for a given amount of hydrogen consumed, while $C_{1}-C_{3}$ gas selectivity is the amount of $C_{1}-C_{3}$ gas obtained for a given amount of distillate produced. Figure 8 shows that the hydrogen efficiency is not significantly different for the first five conditions, 7.3 to $7.8 \%$, but then increased sharply to $8.8 \%$ for condition 6 which is the most hydrogen efficient condition. The $\mathrm{C}_{1}-\mathrm{C}_{3}$ gas selectivity ranges 
from 0.18 to 0.22 with the best efficiency (lowest $\mathrm{C}_{1}-\mathrm{C}_{3}$ gas selectivity) occurring in conditions 1 and 6 , which correspond to the conditions with the greatest distillate yields. The lest attractive conditions (highest $C_{1}-C_{3}$ gas selectivity) are conditions 3 and 4 with had the lowest distillate yields and the highest light-gas yields. 


\section{PRODUCT QUALITY}

Analytical results are presented for the liquid product fractions, namely the separator overhead product and the vacuum still overhead product, as well as for the vacuum still bottoms and the pressure filter solids. The separator overhead and the vacuum still overhead constitute the total distillate product.

\section{Separator Overhead (SOH)}

Table 3 shows the properties for the SOH oil. The SOH oil is the hydrotreated product from the combined HTU feed composed of the light materials generated in the first and second stage liquefaction reactors. It is the major product of coal liquefaction, and has a fairly high $\mathrm{H} / \mathrm{C}$ atomic ratio, close to the petroleum counterpart. The boiling range $\left(50-350^{\circ} \mathrm{C}\right)$ shows that it is mainly gasoline and diesel fuel. The API gravities varied from 35 to $37^{\circ} \mathrm{C}$ and the $\mathrm{H} / \mathrm{C}$ atomic ratios were about 1.85 , except for 1.92 in condition 1 , possibly due to the high initial activity of the HTU catalyst. The heteroatom content of the SOH is low, especially the nitrogen content, which decreased from 0.23 to $0.0 \%$ as the run proceeded. The relatively high sulfur level $(0.17$ to $0.27 \%$ ) is mainly due to $\mathrm{H}_{2} \mathrm{~S}$ and elemental sulfur dissolved in the oil, which can be eliminated by steam stripping in commercial operation.

\section{Vacuum Still Overhead (VSOH)}

The properties of the VSOH are shown in Table 4. Distillation results show that about half of the $\mathrm{VSOH}$ is light distillate, which is a diesel fuel fraction, while the remaining half is a heavy distillate, which is a good FCC feedstock. The API gravity ranged from 5.5 to $11.0^{\circ}$, and the initial boiling point was about $220^{\circ} \mathrm{C}$. The $\mathrm{H} / \mathrm{C}$ atomic ratio varied from a high of 1.29 during condition 1 to a low of 1.14 during condition 6 . The nitrogen levels were around $0.85 \%$, except during condition 1 , when it had a value of $0.49 \%$. The sulfur levels varied from $0.08 \%$ to $0.49 \%$.

\section{Vacuum Still Bottoms (VSB)}

The properties of the VSB are shown in Table 5. VSB is the major component of the recycle solvent. The gravity was very low $\left(-15\right.$ to $\left.-17^{\circ} \mathrm{API}\right)$ and the initial boiling point was at least $340^{\circ} \mathrm{C}$, except for condition 6 which has an initial boiling point of $401^{\circ} \mathrm{C}$ when the vacuum distillation cut point was raised from $426^{\circ} \mathrm{C}$ to $454^{\circ} \mathrm{C}$. The $\mathrm{H} / \mathrm{C}$ atomic ratio ranged from 0.75 to 0.87 . The nitrogen level ranged from 0.95 to $1.07 \%$, except for condition 1 which was $0.83 \%$. The sulfur levels varied from 0.17 to $0.36 \%$. 
Pre-asphaltenes and asphaltenes concentrated in the VSB. As the vacuum distillation cut point was increased by $28^{\circ} \mathrm{C}$, the pre-asphaltenes and asphaltenes content of VSB was highest in condition 6 .

\section{Pressure Filter Solids (PFS)}

The solids derived from filtration are oil containing solids, which are extracted with toluene to recover the oils. The oil-free solid is then analyzed to determine the extent of coal conversion, based upon the solubility of the PFS in quinoline. The properties of the PFS are shown in Table 6. The $\mathrm{H} / \mathrm{C}$ atomic ratios of PFS ranged from 0.58 to 0.73 , and the quinoline insolubles, including ash, ranged from 58 to $73 \%$.

\section{Characterization of Total Distillate Product}

The total distillate product, composed of SOH and VSOH proportionally, was subjected to the True-Boiling-Point (TBP) distillation, followed by analysis of the TBP fractions. The analytical results for the total distillate products from conditions 1 and 6 are summarized in Tables 7 and 8 . These two conditions were chosen because they gave the best results for the two coals tested in this run. 


\section{Discussion of Process Performance Results}

\section{Effect of Coal Feed Type}

The data shows that under the optimum condition chosen for each coal during the run, both coals performed well, while Shenhua \#3 Coal had a superior performance over Shenhua \#2, as depicted in Figures 9 and 10. While the coal conversions were essentially the same with the two coals, the $524^{\circ} \mathrm{C}^{+}$residuum conversion was substantially higher with Shenhua \#3 coal than with Shenhua \#2 coal. The superiority of the Shenhua \#3 coal was further evidenced by the higher $\mathrm{C}_{4^{-}}$ $524^{\circ} \mathrm{C}$ distillate yield and the lower $524^{\circ} \mathrm{C}^{+}$residuum yield, even though the $\mathrm{C}_{1}-\mathrm{C}_{3}$ light gas yields were slightly lower when Shenhua \#2 coal was used. The differences between Shenhua \#2 and Shenhua \#3 coals are not excessive though, and could be largely attributed to the process conditions employed, since the two coals were not tested under the same exact conditions.

Product yield, however, should not be the only criterion in comparing the liquefaction performance of the two coals. As shown in Figure 8, using the Shenhua \#2 coal improved the hydrogen efficiency over the Shenhua \#3 coal, which may compensate for the lower distillate yield in the economic analysis.

\section{Effect of GelCat ${ }^{\text {TM }}$ Formulation and Loading}

As mentioned previously, two catalyst formations were used in PB-09. L-942 and L-945 had $\mathrm{Fe} /$ promoter atomic ratios of 100/4, while L-943 has a Fe/promoter atomic ratio of 100/2. Comparisons of the two types of GelCat ${ }^{\mathrm{TM}}$ catalysts employed in this run are depicted in Figures 11 and 12. L-942 gave higher coal and $524^{\circ} \mathrm{C}^{+}$residuum conversions than L-943. L-942 also produced higher yields of $\mathrm{C}_{4}-524^{\circ} \mathrm{C}+$ distillate and lower yields of $\mathrm{C}_{1}-\mathrm{C}_{3}$ light gas and $524^{\circ} \mathrm{C}^{+}$ residuum yields. Therefor, the L-942 catalyst with the higher promoter loading was superior in converting the residuum and in producing a distillate product.

Catalyst loadings tested in this run show that increasing catalyst usage beyond $5,000 \mathrm{ppm}$ would increase light ends (gas and naphtha) yields, but would reduce the total liquids yield. 


\section{Operational Parameters}

Results from conditions 4 and 5 clearly indicate that the total distillate $\left(\mathrm{C} 4-524^{\circ} \mathrm{C}\right)$ yield is sensitive to the change in reactor temperature and space velocity. Since the operating parameters in condition 1 were selected based on experimental results previously obtained by CCRI and HTI, they appeared to be close to optimal, at least for the Shenhua \#3 coal, as demonstrated in PB-09. An increase in space velocity or a decrease in the first-stage reactor temperature resulted in a substantial reduction in residuum conversion and in lower distillate yield. Shenhua coal liquefaction tests conducted at CCRI gave coal conversion of $88 \%$ and distillate yield of $60.7 \% *$, lower than those achieved in Run PB-09 using HTI coal liquefaction technology and HTI's proprietary GelCat ${ }^{\mathrm{TM}}$ catalyst.

Test results clearly indicate that for both coals, conversion above $90 \%$ was not difficult to achieve. However, attempts to raise coal conversion beyond $92-93 \%$ were not successful. This is obviously restricted by the high content of inert components in Shenhua coals. Residuum conversion as well as distillate yields, however, are fairly high, relative to coals of similar rank. Operating conditions and catalyst loading/ formulations can be further adjusted to improve liquefaction performance of Shenhua coals, \#2 coal in particular.

Since the number of conditions studied in the test is limited, conditions 1 and 6 represent only the best results achieved in this run, and may not be optimum conditions for the two coals. Other parameters, such as recycle ratio and composition have not yet been carefully studies. This means that there is considerable room for improvement of liquefaction performance of the Shenhua coals, in further studies.

* Jin Jialu et al. Proceedings of International Symposium on Clean Coal Technology, Nov. 1997, Xiamen, China, pp777-781. 


\section{TECHNO-ECONOMIC ASSESSMENT}

Economics were assessed for six conditions of PB-09, using the yields and operating conditions previously presented. The basis was a grass-roots liquefaction complex, feeding 12,000 tons/day of coal, at a US Gulf Coast location.

Table 9 presents the material balances for the conditions assessed. Product yields are seen relatively high in conditions 1,2 , and 6 and notably poorer in conditions 3 through 5 . Byproduct propane and butane are high in all conditions but especially in conditions 2 and 3 .

Table 10 shows hydrogen balances, utility requirements, and thermal efficiencies for the conditions. Conditions 4 and 5 show an appreciably lower total hydrogen consumption, but because of the decreased product yield the hydrogen used per barrel of product is higher than the other conditions.

The capacities of the process units and off-sites are summarized in Table 11.

The details of the liquefaction plan investment estimates are shown in Table 12. Due to the higher space velocity, condition 4 has a lower reactor cost than the other cases but outside of this condition, the investment costs are within $\pm 1 \%$ of each other.

The total plant investment costs are summarized in Table 13. Conditions 3 and 4 show about a 4 percent lower total plant investment than the others, because of reduced hydrogen plant cost. Again, however the decreased product yield increases the cost per daily barrel of product. The lowest cost per BPSD is found for condition 1.

Table 14 is a summary of the product costs and Table 15 itemizes the equivalent crude price by categories. By far the best economics are obtained in condition 1, with condition 6 in second place. Conditions 4 and 5 show the poorest economics because of lower product yield and higher hydrogen consumption per barrel of product.

Outside of capital-related costs, coal cost and natural gas cost account for the biggest contribution to equivalent crude price. The coal price used in this analysis was set by China authorities. Figure 13 shows the sensitivity of the coal cost, and Figure 14 shows the effect of the natural gas price on the equivalent crude price. 


\section{CONCLUSIONS}

The following conclusions were found from Bench Run PB-09:

- The promoter-modified GelCat ${ }^{\mathrm{TM}}$ catalyst proved to be successful direct liquefaction catalyst. Coal conversion was as high as $93 \%$ maf and $524^{\circ} \mathrm{C}^{+}$residuum conversion went as high as $85 \%$ maf.

- The promoter-modified GelCat ${ }^{\mathrm{TM}}$ also enhanced product yield as evidenced by $\mathrm{C}_{4^{-}}-524^{\circ} \mathrm{C}$ distillate yields as high as $67 \%$ maf.

- Both Shenhua \#3 and \#2 coals had good liquefaction performance, with coal conversion in the range of $91-93 \%$ maf. However, $524^{\circ} \mathrm{C}^{+}$residuum conversions were higher for Shenhua \#3 coal than for Shenhua \#2 coal, $85 \%$ maf versus $80 \%$ maf.

- The selectivity of products derived from the direct liquefaction of Shenhua \#3 coal proved to be more superior than products derived from Shenhua $\# 2$ coal: $\mathrm{C}_{4}-524^{\circ} \mathrm{C}$ distillate yields were higher, $67 \%$ maf vs. $60 \%$ maf, $524^{\circ} \mathrm{C}^{+}$residuum yields were lower, $7 \%$ maf vs. $13 \%$ maf, while $\mathrm{C}_{1}-\mathrm{C}_{3}$ light gas yields were slightly higher, $13 \%$ maf vs. $11 \%$ maf.

- Shenhua \#3 coal appeared more economically attractive than Shenhua \#2 coal. The most favorable economic results were obtained using commercial projections from Condition 1.

- Coal conversin and distillate yield achieved in Bench run PB-09 on Shenhua coal using HTI coal liquefaction technology and GelCat ${ }^{\mathrm{TM}}$ catalyst exceeded those obtained at CCRI. 


\section{Table 1. Feed Coal Analysis}

Shenhua Coal Number

HTI Designation

Moisture Content, W\%
2

6769

8.31
3

6770

9.4
W\% dry

PROXIMATE ANALYSIS

Fixed Carbon

Volatile matter

Ash

ULTIMATE ANALYSIS

Carbon

Hydrogen

Nitrogen

Sulfur

Oxygen

Ash

TOTAL

H/C atomic Ratio
57.95

35.84

6.21

75.87

4.24

0.98

0.42

12.28

6.21

100.00

0.67
W\% daf

61.79

38.21

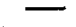

80.90

4.52

1.04

0.45

13.09

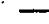

100.00

4.13

10.68

4.25

100.00

100.00
79.47

1.05

0.42

61.91

38.09

6.47

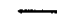

83.00

4.31

1.10

0.44

11.15

0.62 
Table 2. Process Performance Summary

\begin{tabular}{|c|c|c|c|c|c|c|}
\hline $\begin{array}{l}\text { Condition } \\
\text { Periods } \\
\text { Work-up Period }\end{array}$ & $\begin{array}{c}1 \\
1-4 \\
4\end{array}$ & $\begin{array}{c}2 \\
5-10 \\
10\end{array}$ & $\begin{array}{c}3 \\
11-15 \\
15\end{array}$ & $\begin{array}{c}4 \\
16-19 \\
19\end{array}$ & $\begin{array}{c}5 \\
20-23 \\
23\end{array}$ & $\begin{array}{c}6 \\
24-29 \\
29\end{array}$ \\
\hline \multicolumn{7}{|l|}{ Process Conditions } \\
\hline Coal type (Shenhua \#) & 3 & 3 & 3 & 3 & 2 & \\
\hline Space velocity, $\mathrm{kg} / \mathrm{hr} / \mathrm{m}^{3}$ & 449 & 444 & 446 & 529 & 455 & 455 \\
\hline Temperature, $\mathrm{K}-1,{ }^{\circ} \mathrm{C}$ & 440 & 440 & 440 & 440 & 435 & 443 \\
\hline Temperature, $\mathrm{K}-2,{ }^{\circ} \mathrm{C}$ & 450 & 450 & 450 & 450 & 450 & 450 \\
\hline Catalyst type & L-942 & L-943 & L-942 & L-942 & L-945 & L-945 \\
\hline Catalyst loading, $\mathrm{Fe}, \mathrm{ppm}$ & 5000 & 7500 & 7500 & 7500 & 7500 & 5000 \\
\hline Recyc & 1.5 & 1.5 & 1.5 & 1.5 & 1.5 & 1.5 \\
\hline Solids/MF coal & 0.15 & 0.15 & 0.17 & 0.15 & 0.17 & 0.10 \\
\hline \multicolumn{7}{|l|}{ Normalized yields, w\% maf feed } \\
\hline $\mathrm{C}_{1}$ & 4.40 & 4.52 & 4.53 & 4.15 & .77 & 3.89 \\
\hline $\mathrm{C}_{2}$ & 3.72 & 3.89 & 3.81 & 3.45 & 3.06 & 3.26 \\
\hline $\mathrm{C}_{3}$ & 4.48 & 4.75 & 4.94 & 4.34 & 3.94 & 4.3 \\
\hline $\mathrm{C}_{4}$ & 2.80 & 2.80 & 3.05 & 2.65 & 2.42 & 2.70 \\
\hline $\mathrm{C}_{5}$ & 1.51 & 1.58 & 1.59 & 1.02 & 1.06 & 0.68 \\
\hline $\mathrm{C}_{6} \& \mathrm{C}_{7}$ gases & 1.10 & 1.31 & 1.34 & 1.35 & 0.99 & 1.13 \\
\hline $\mathrm{C}_{1}-\mathrm{C}_{3}$ & 12.60 & 13.16 & 13.28 & 11.94 & 10.77 & 11.49 \\
\hline $\mathrm{C}_{4}-\mathrm{C}_{7}$ gases & 5.41 & 5.73 & 5.98 & 5.02 & 4.47 & 4.51 \\
\hline $\mathrm{IBP}-177^{\circ} \mathrm{C}$ & 9.75 & 12.33 & 12.45 & 8.55 & 10.54 & 10.14 \\
\hline $177-260^{\circ} \mathrm{C}$ & 11.97 & 11.76 & 10.98 & 8.26 & 9.10 & 9.35 \\
\hline 26 & 21.93 & 16.57 & 15.02 & 13.06 & 12.52 & 14.47 \\
\hline $343-399^{\circ} \mathrm{C}$ & 12.98 & 10.38 & 6.86 & 7.63 & 8.38 & 15.44 \\
\hline $399-454^{\circ} \mathrm{C}$ & 4.48 & 5.09 & 4.09 & 4.97 & 4.58 & 6.42 \\
\hline $454-524^{\circ} \mathrm{C}$ & 1.45 & 3.20 & 3.09 & 4.52 & 4.57 & 3. \\
\hline $524^{+0} \mathrm{C}$ & 7.39 & 8.63 & 13.41 & 21.58 & 19.84 & 12.84 \\
\hline Unconve & 8.06 & 8.39 & 9.21 & 8.81 & 9.36 & 6.81 \\
\hline Water & 10.63 & 10.73 & 11.25 & 10.51 & 11.13 & 10. \\
\hline $\mathrm{CO}$ & 0.28 & 0.23 & 0.25 & 0.20 & 0.23 & 0.26 \\
\hline $\mathrm{CO}_{2}$ & 1.12 & 1.07 & 1.22 & 0.96 & 0.98 & 0.84 \\
\hline $\mathrm{NH}_{3}$ & 1.03 & 0.95 & 0.88 & 0.67 & 0.74 & 0.76 \\
\hline $\mathrm{H}_{2} \mathrm{~S}$ & -0.27 & 0.07 & -0.01 & 0.11 & -0.11 & -0.0 \\
\hline \multicolumn{7}{|l|}{ Process performance, W\% maffec } \\
\hline ersion & 91.8 & 91.4 & 90.0 & 91.0 & 90.5 & 93 \\
\hline $524^{\circ} \mathrm{C}^{+}$residuum conversion & 84.5 & 82.7 & 77.3 & 69.5 & 70.7 & 80.3 \\
\hline $\mathrm{C}_{4}-524^{\circ} \mathrm{C}$ distillate yield & 68.0 & 65.1 & 58.5 & 52.0 & 54.2 & 63.4 \\
\hline $\mathrm{C}_{4}-399^{\circ} \mathrm{C}$ distillate yield & 59.2 & 53.9 & 48.2 & 39.9 & 42.6 & 51.2 \\
\hline $\mathrm{H}_{2}$ consumption & 8.80 & 8.31 & 7.95 & 6.81 & 7.11 & 7.25 \\
\hline Material recove & 100.8 & 00.1 & 102 & 101.4 & 101.5 & \\
\hline
\end{tabular}

All conditions utilized a hydrotreater $\left(379^{\circ} \mathrm{C}\right)$, an interstage separator, and solid recycle 
Table 3. Separator Overhead (SOH) Properties

\begin{tabular}{|c|c|c|c|c|c|c|}
\hline Condition & 1 & 2 & 3 & 4 & 5 & 6 \\
\hline Period & 4 & 10 & 15 & 19 & 23 & 29 \\
\hline Gravity, ${ }^{\circ} \mathrm{API}$ & 36.9 & 35.0 & 36.2 & 36.4 & 36.6 & 37.0 \\
\hline $\mathrm{IBP},{ }^{\circ} \mathrm{C}$ & 58 & 50 & 60 & 52 & 51 & 56 \\
\hline $\mathrm{FBP},{ }^{\circ} \mathrm{C}$ & 340 & 339 & 330 & 339 & 349 & 349 \\
\hline \multicolumn{7}{|c|}{ Elemental Analysis, W\% } \\
\hline C & 86.15 & 86.62 & 85.92 & 85.81 & 86.16 & 86.39 \\
\hline $\mathbf{H}$ & 13.87 & 13.49 & 13.35 & 13.29 & 13.41 & 13.39 \\
\hline $\mathrm{N}$ & 0.23 & 0.20 & 0.04 & 0.04 & 0.04 & 0.00 \\
\hline$S$ & 0.17 & 0.19 & 0.23 & 0.55 & 0.25 & 0.27 \\
\hline $\mathrm{H} / \mathrm{C}$ atomic ratio & 1.92 & 1.86 & 1.85 & 1.85 & 1.85 & 1.85 \\
\hline \multicolumn{7}{|c|}{ ASTM Distillation, W\% } \\
\hline $\mathrm{IBP}-177^{\circ} \mathrm{C}$ & 26.7 & 32.2 & 35.5 & 34.6 & 33.3 & 34.4 \\
\hline $177-260^{\circ} \mathrm{C}$ & 28.7 & 27.9 & 28.0 & 28.2 & 26.5 & 26.1 \\
\hline $260-343^{\circ} \mathrm{C}$ & 36.4 & 30.7 & 29.0 & 28.0 & $28 . .56$ & 27.9 \\
\hline $343{ }^{\circ} \mathrm{C}+$ & 8.2 & 9.2 & 7.5 & 9.2 & 11.7 & 11.7 \\
\hline TOTAL & 100.0 & 100.0 & 100.0 & 100.0 & 100.0 & 100.0 \\
\hline
\end{tabular}


Table 4. Vacuum Still Overheads (VSOH) Properties

$\begin{array}{lrrrrrr}\text { Condition } & 1 & 2 & 3 & 4 & 5 & 6 \\ \text { Period } & 4 * & 10 & 15 & 19 & 23 & 29 \\ & & & & & & \\ \text { Gravity, }{ }^{\circ} \mathrm{API} & 11.0 & 8.3 & 7.0 & 7.5 & 8.9 & 5.5 \\ \mathrm{IBP},{ }^{\circ} \mathrm{C} & 226 & 215 & 222 & 225 & 213 & 233\end{array}$

Elemental Analysis, W\%

$\begin{array}{ccccccc}\mathrm{C} & 88.32 & 88.22 & 88.20 & 87.13 & 87.84 & 88.53 \\ \mathrm{H} & 9.55 & 8.80 & 8.62 & 8.77 & 9.09 & 8.48 \\ \mathrm{~N} & 0.49 & 0.77 & 0.80 & 0.92 & 0.87 & 0.88 \\ \mathrm{~S} & 0.49 & 0.09 & 0.42 & 0.08 & 0.12 & 0.32 \\ \mathrm{H} / \mathrm{C} \text { atomic ratio } & 1.29 & 1.19 & 1.16 & 1.20 & 1.23 & 1.14\end{array}$

ASTM Distillation, W\%

$\begin{array}{lcccccc}\mathrm{IBP}-343^{\circ} \mathrm{C} & 45.5 & 55.3 & 44.5 & 52.7 & 59.9 & 28.7 \\ 343-454^{\circ} \mathrm{C} & 45.8 & 43.4 & 43.6 & 45.4 & 33.7 & 49.4 \\ 454-524^{\circ} \mathrm{C} & 8.7 & 1.4 & 11.8 & 1.9 & 6.4 & 20.2 \\ 524^{\circ} \mathrm{C}+ & 0.0 & 0.0 & 0.0 & 0.0 & 0.0 & 1.7 \\ & & & & & & \\ \text { TOTAL } & 100.0 & 100.0 & 100.0 & 100.0 & 100.0 & 100.0\end{array}$

*Sub-period " $A$ " only 
Table 5. Vacuum Still Bottoms (VSB) Properties

$\begin{array}{lcccccc}\text { Condition } & 1 & 2 & 3 & 4 & 5 & 6 \\ \text { Period } & 4 & 10 & 15 & 19 & 23 & 29 \\ & & & & & & \\ \text { Gravity, }{ }^{\circ} \mathrm{API} & -14.8 & -14.5 & -15.4 & -14.9 & -14.8 & -16.7 \\ \text { IBP, }{ }^{\circ} \mathrm{C} & 356 & 340 & 350 & 345 & 347 & 401 \\ & & & & & & \\ \text { Elemental Analysis, } \boldsymbol{W \%}^{-} & & & & & & \\ \mathrm{C} & & & & & & \\ \mathrm{H} & 89.75 & 90.28 & 90.74 & 89.59 & 90.58 & 90.53 \\ \mathrm{~N} & 6.56 & 6.23 & 5.95 & 6.06 & 6.29 & 5.68 \\ \mathrm{~S} & 0.83 & 0.97 & 0.95 & 1.01 & 1.07 & 1.06 \\ \mathrm{H} / \mathrm{C} \text { atomic ratio } & 0.29 & 0.26 & 0.19 & 0.19 & 0.25 & 0.26 \\ & 0.87 & 0.82 & 0.78 & 0.81 & 0.83 & 0.75\end{array}$

ASTM Distillation, W\%

$\begin{array}{lcccccc}\mathrm{IBP}-3.85^{\circ} \mathrm{C} & 8.1 & 11.5 & 8.5 & 9.3 & 8.2 & 0.0 \\ 343-454^{\circ} \mathrm{C} & 21.9 & 15.7 & 14.5 & 23.4 & 12.8 & 10.0 \\ 454-524^{\circ} \mathrm{C} & 10.1 & 14.4 & 14.8 & * * & 13.8 & 15.9 \\ 524^{\circ} \mathrm{C}+ & 59.9 & 58.4 & 62.2 & 67.3 & 65.2 & 74.1 \\ & & & & & & \\ \text { TOTAL } & 100.0 & 100.0 & 100.0 & 100.0 & 100.0 & 100.0\end{array}$

Solvent Extraction, W\%

$\begin{array}{llllllll}\text { Toluene Insolubles } & 19.0 & 28.0 & 29.5 & 26.98 * & 28.47^{*} & 32.2\end{array}$

$\begin{array}{lllllll}\text { Cyclohexane Insolubles } & 55.9 & 78.6 & 77.1 & 79.27^{*} & 82.91^{*} & 93.7\end{array}$

*Sub-period "A" only

** Combined $385-454^{\circ} \mathrm{C}$ and $454-524^{\circ} \mathrm{C}$ fractions for period 19 
Table 6. Pressure Filter Solids (PFS) Properties

Condition

Period

Elemental Analysis, W\%

$\mathrm{C}$

$\mathrm{H}$

$\mathrm{N}$

$\mathrm{S}$

$\mathrm{H} / \mathrm{C}$ atomic ratio

Composition, W\%

Quinoline solubles

Ash-free quinoline insolubles

Ash

TOTAL

Sulfur content of ash, W\%

Solvent Extraction, W\%

Toluene Insolubles

Cyclohexane Insolubles

$\begin{array}{cccccc}1 & 2 & 3 & 4 & 5 & 6 \\ 4 & 10 & 15 & 19 & 23 & 29\end{array}$

$\begin{array}{cccccc}66.34 & 61.35 & 64.05 & 62.32 & 53.47 & 51.4 \\ 4.08 & 3.37 & 3.42 & 3.39 & 2.84 & 2.49 \\ 0.49 & 0.55 & 0.56 & 0.62 & 0.00 & 0.48 \\ 3.50 & 4.74 & 3.97 & 3.79 & 4.93 & 3.94 \\ 0.73 & 0.65 & 0.63 & 0.64 & 0.63 & 0.58\end{array}$

$\begin{array}{llllll}41.7 & 36.6 & 38.8 & 38.8 & 32.1 & 27.0\end{array}$

$\begin{array}{llllll}34.9 & 36.1 & 33.8 & 32.8 & 29.8 & 33.3\end{array}$

$\begin{array}{llllll}23.4 & 27.3 & 27.4 & 28.4 & 38.1 & 39.7\end{array}$

$\begin{array}{llllll}100.0 & 100.0 & 100.0 & 100.0 & 100.0 & 100.0\end{array}$

$\begin{array}{lllllll}2.8 & 4.1 & 3.2 & 3.6 & 9.9 & 9.3\end{array}$

$\begin{array}{llllll}47.3 & 70.8 & 67.0 & 68.0 & 72.4 & 82.9\end{array}$

$\begin{array}{llllll}73.4 & 80.9 & 78.3 & - & - & -\end{array}$ 


\section{Table 7. Characterization of Total Distillate Product for Condition 1}

Cut, ${ }^{\circ} \mathrm{C}$

Weight \% of Total

Gravity, ${ }^{\circ} \mathrm{API}$

Specific Gravity $\left(18^{\circ} \mathrm{C}\right)$

Carbon, W\%

Hydrogen, W\%

Nitrogen, ppm

Sulfur, ppm

CCR, W\%

Ash (ASTM), W\%

Heptane Insolubles, W\%

Basic Nitrogen, ppm

Pour Point, ${ }^{\circ} \mathrm{C}$

Freezing Point, ${ }^{\circ} \mathrm{C}$

Aniline Point, ${ }^{\circ} \mathrm{C}$

Viscosity, cst @ $38^{\circ} \mathrm{C}$

Viscosity, cst @23.3 ${ }^{\circ} \mathrm{C}$

Smoke Point, mm

Copper Corrosion, ASTM D130

Existent Gum, $\mathrm{mg} / 100 \mathrm{~mL}$

$\begin{array}{cccccc}\text { IBP-82 } & 82-204 & 204-288 & 288-343 & 343-524 & \text { WHOLE } \\ 1.60 & 22.05 & 32.45 & 26.15 & 17.75 & 100.00 \\ 60.8 & 46.4 & 29.1 & 23.5 & 15.0 & 29.7 \\ 0.7358 & 0.7954 & 0.8811 & 0.9129 & 0.959 & 0.8778 \\ 84.51 & 85.17 & 87.30 & 87.96 & 88.01 & 87.62 \\ 14.86 & 14.02 & 12.88 & 12.35 & 10.70 & 12.68 \\ 4 & 145 & 264 & 1,236 & 5,145 & 1,387 \\ <1 & 11 & 475 & 1,061 & 4,798 & 989 \\ & & & & 0.610 & 0.007 \\ & & & & & 0.00 \\ & & & & & 0.06 \\ & & & & & 663\end{array}$

$-13.1$

$\begin{array}{llll}-57 & -21 & 13 & -32\end{array}$

$\begin{array}{llll}47.2 & 50.8 & 51.7 & \text { too dark } \quad 53.1\end{array}$

$\begin{array}{lll}2.63 & 7.10 & 2.90\end{array}$

3.69

12.6

$1 \mathrm{~A}$

11.4

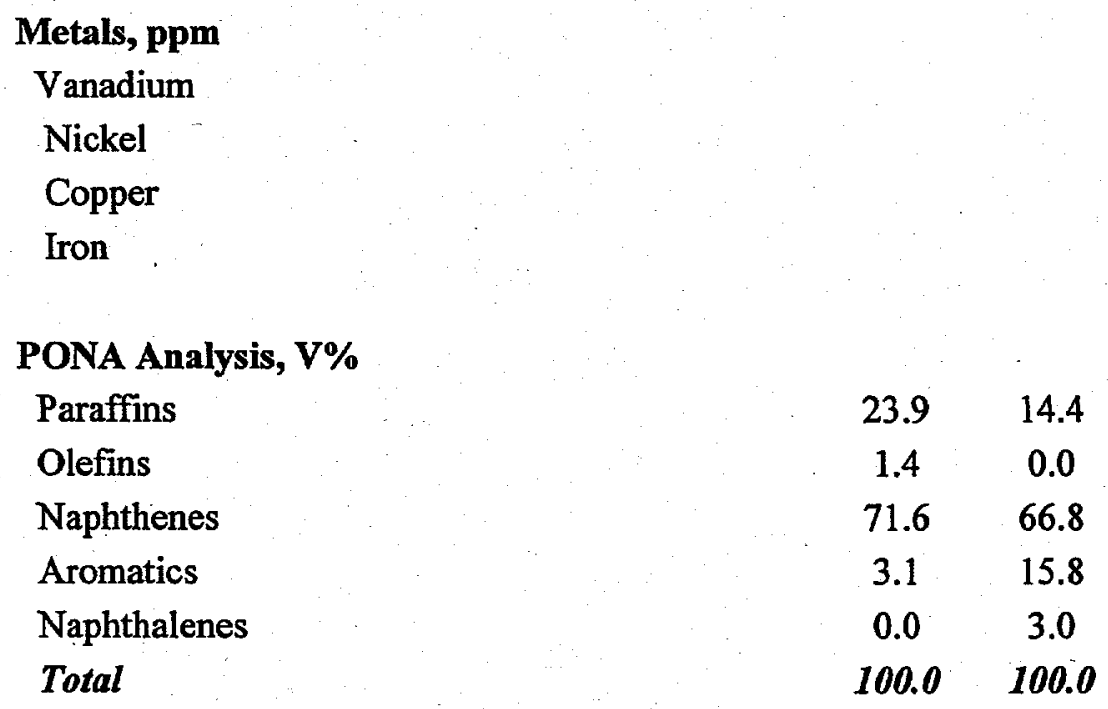


Table 8. Characterization of Total Distillate Product for Condition 2

\begin{tabular}{|c|c|c|c|c|c|c|}
\hline Cut, ${ }^{\circ} \mathrm{C}$ & $I B P-82$ & $82-204$ & $204-288$ & $288-343$ & $343-524$ & WHOLE \\
\hline Weight $\%$ of Total & 2.15 & 23.75 & 22.50 & 17.20 & 34.40 & 100.00 \\
\hline Gravity, ${ }^{\circ} \mathrm{API}$ & 61.2 & 45.6 & 24.2 & 14.8 & 5.8 & 22.5 \\
\hline Specific Gravity $\left(18^{\circ} \mathrm{C}\right)$ & 0.7343 & 0.7990 & 0.9088 & 0.9672 & 1.0306 & 0.9188 \\
\hline Carbon, W\% & 84.76 & 85.25 & 87.42 & 87.98 & 89.06 & 87.90 \\
\hline Hydrogen, W\% & 14.97 & 13.84 & 11.91 & 10.65 & 9.04 & 11.28 \\
\hline Nitrogen, ppm & $<1$ & 183 & 354 & 3,316 & 8,745 & 3,003 \\
\hline Sulfur, ppm & $<1$ & 14 & 156 & 891 & 4,824 & 870 \\
\hline CCR, W\% & & & & & 0.626 & 0.116 \\
\hline Ash (ASTM), W\% & & & & & & 0.00 \\
\hline Heptane Insolubles, W\% & & & $\therefore$ & & & 0.65 \\
\hline Basic Nitrogen, ppm & & & & & & 2,388 \\
\hline Pour Point, ${ }^{\circ} \mathrm{C}$ & & & & -12.0 & & \\
\hline Freezing Point, ${ }^{\circ} \mathrm{C}$ & & & -59 & -18 & -21 & -42 \\
\hline Aniline Point, ${ }^{\circ} \mathrm{C}$ & & 43 & 51 & 59 & too dark & 46 \\
\hline Viscosity, cst@38 $38^{\circ} \mathrm{C}$ & & & 2.99 & 12.09 & & 4.34 \\
\hline Viscosity, cst@23.3ㄷ & & & 4.17 & & & \\
\hline Smoke Point, mm & & & 10.3 & & & \\
\hline Copper Corrosion, ASTM D130 & & & & & $1 \mathrm{~A}$ & \\
\hline Existent Gum, mg/100 mL & & 12.4 & & & & \\
\hline Metals, ppm & & & & & & \\
\hline Vanadium & & & & & & $<1$ \\
\hline Nickel & & & & & & $<1$ \\
\hline Copper & & & & & & $<1$ \\
\hline Iron & & & & & & 1.4 \\
\hline \multirow{2}{*}{\multicolumn{7}{|c|}{ PONA Analysis, V\% }} \\
\hline & & & & & & \\
\hline Paraffins & & 21.5 & 5.8 & & & \\
\hline Olefins & & 1.1 & 0.0 & & & \\
\hline Naphthenes & & 71.0 & 61.4 & & & \\
\hline Aromatics & & 6.4 & 28.8 & & & \\
\hline Naphthalenes & & 0.0 & 4.0 & & & \\
\hline Total & & 100.0 & 100.0 & & & \\
\hline
\end{tabular}


Table 9. Material Balance for Economic Assessment

\begin{tabular}{|c|c|c|c|c|c|c|}
\hline & & & al type, & henhua \# & & \\
\hline & & 3 & & & 2 & \\
\hline Condition & $\underline{1}$ & $\underline{2}$ & $\underline{3}$ & 4 & $\underline{5}$ & $\underline{6}$ \\
\hline Feed to Liquefaction & & & & & & \\
\hline Coal, T/D & 12,000 & 12,000 & 12,000 & 12,000 & 12,000 & 12,000 \\
\hline Liquid Products, $B / D$ & & & & & & \\
\hline Gasoline & 15,059 & 14,077 & 12,486 & 10,801 & 10,980 & 13,524 \\
\hline Diesel Fuel & 35,582 & 33,260 & 29,501 & 25,521 & 25,944 & 31,953 \\
\hline Total & 50,641 & 47,337 & 41,987 & 36,322 & 36,924 & 45,477 \\
\hline Bbl Product/Ton Feed & 4,22 & 3.94 & 3.50 & 3.03 & 3.08 & 3.79 \\
\hline By-Products & & & & & & \\
\hline Propane, B/D & 5,713 & 6,046 & 6,264 & 5,494 & 4,900 & 5,417 \\
\hline Butane, $B / D$ & 3,365 & 3,407 & 3,607 & 3,132 & 2,823 & 3,166 \\
\hline Sulfur, T/D & 35 & 36 & 38 & 38 & 37 & 32 \\
\hline Ammonia, T/D & 118 & 109 & 101 & 77 & 83 & 86 \\
\hline Waste to Disposal, T/D & 527 & 530 & 537 & 546 & 777 & 766 \\
\hline
\end{tabular}


Table 10. Hydrogen Balance, Utilities \& Thermal Efficiency

Condition

\section{Hydrogen Balance}

Hydrogen Consumption, $10^{6}$ SCFD

Liquefaction

Product Upgrading

Solution \& Purge Losses

Total

Hydrogen used, SCF/Bbl

Hydrogen Production, $10^{6}$ SCFD

Partial Oxidation

Steam Reforming

Total

\section{Hydrogen Balance}

Power, MW

Steam, 600 Psig, $10^{3} \mathrm{lb} / \mathrm{hr}$

Cooling water, $10^{3} \mathrm{GPM}$

Natural Gas, $10^{9}$ BTU/D

Raw water, $10^{3} \mathrm{Gal} / \mathrm{D}$

Thermal Efficiency

Inputs, $10^{9}$ BTU/Day

Feed

Natural Gas

Total

Outputs, $10^{9}$ BTU/Day

Gasoline

Diesel Fuel

Propane \& Butane

Sulfur \& Ammonia

Total

Thermal Efficiency, HHV $\begin{array}{llllll}1 & 2 & \underline{3} & \underline{4} & \underline{5} & \underline{6}\end{array}$

6


Table 11. Capacities of Process Units \& Offsites

\begin{tabular}{|c|c|c|c|c|c|c|c|}
\hline $\begin{array}{l}\text { Condition } \\
\text { Area or Item }\end{array}$ & Sizing Basis & 1 & $\underline{2}$ & $\underline{\mathbf{3}}$ & 4 & 5 & $\underline{6}$ \\
\hline Coal Preparation & $T / D$ dry coal & 12,000 & 12,000 & 12,000 & 12,000 & 12,000 & 12,000 \\
\hline Liquefaction & T/D total feed & 12,000 & 12,000 & 12,000 & 12,000 & 12,000 & 12,000 \\
\hline \multicolumn{8}{|l|}{$\mathrm{H}_{2}$ Manufacture } \\
\hline Steam Reforming & $10^{6} \mathrm{SCFD} \mathrm{H}_{2}$ & 287.1 & 243.3 & 165.0 & 43.5 & 58.9 & 202.2 \\
\hline Partial Oxidation & $10^{6} \mathrm{SCFD} \mathrm{H}_{2}$ & 154.9 & 186.1 & 245.2 & 322.1 & 291.5 & 183.4 \\
\hline Oxygen Plant & T/D Oxygen & 1,922 & 2,312 & 3,048 & 4,009 & 3,624 & 2,280 \\
\hline \multicolumn{8}{|l|}{ Treating } \\
\hline $\begin{array}{l}\text { Sour water treating } \\
\text { Sulfur recovery }\end{array}$ & $\begin{array}{l}\text { gpm sour water } \\
\text { T/D Sulfur }\end{array}$ & 1,921 & 1,857 & 1,779 & 1,601 & 1,575 & 1,665 \\
\hline $\begin{array}{l}\text { Gas plant } \\
\text { Product Upgrading }\end{array}$ & $\mathrm{lb} / \mathrm{hr} \mathrm{C}_{1}-\mathrm{C}_{3}$ & 120,650 & 126,010 & 127,160 & 114,320 & 101,010 & 107,770 \\
\hline Catalytic Reforming & $\mathrm{B} / \mathrm{D}$ gasoline & 15,059 & 14,077 & 12,486 & 10,801 & 10,980 & 13,524 \\
\hline $\begin{array}{l}\text { Hydrotreating } \\
\text { Utilities }\end{array}$ & B/D liquids & 35,582 & 33,260 & 29,501 & 25,521 & 25,944 & 31,953 \\
\hline Steam generation & $10^{3} \mathrm{lb} / \mathrm{hr}$ & 220 & 215 & 165 & 189 & 143 & 151 \\
\hline Power generation & MW & 268 & 275 & 290 & 298 & 283 & 254 \\
\hline Cooling water & $10^{3} \mathrm{GPM}$ & 187 & 186 & 177 & 168 & 154 & 162 \\
\hline \multicolumn{8}{|l|}{ Tankage } \\
\hline Product Liquids & B/D liquids & 50,641 & 47,337 & 41,987 & 36,322 & 36,924 & 45,477 \\
\hline Propa1 & $\mathrm{B} / \mathrm{D}$ & 9,078 & 9,453 & 9,871 & 8,626 & 7,723 & 8,583 \\
\hline Solids handling & $\mathrm{T} / \mathrm{D}$ & 527 & 530 & 537 & 546 & 777 & 766 \\
\hline General Offsites & $\mathrm{T} / \mathrm{D}$ total feed & 12,000 & 12,000 & 12,000 & 12,000 & 12,000 & 12,000 \\
\hline
\end{tabular}


Table 12. Liquefaction Plant Investment Details

Condition

Major Equipment Cost, $10^{3} \$$

Pumps

Reactor

Fired heaters

Exchangers

Drums

Towers

Compressors

HPU

Total

Plant Investment, $10^{6} \mathrm{~s}$

Materials \& Equipment

Labor \& Subcontracts

Indirects

Total

$1 \quad \underline{2}$

$\underline{3}$

4

$\underline{\mathbf{5}}$

6 $\begin{array}{llllll}22,319 & 22,447 & 22,420 & 22,215 & 22,379 & 22,725\end{array}$

$\begin{array}{llllll}52,237 & 52,657 & 52,657 & 47,085 & 51,798 & 51,798\end{array}$

$\begin{array}{llllll}14,544 & 15,201 & 15,511 & 15,998 & 16,190 & 16,491\end{array}$

$\begin{array}{lllllll}20,615 & 20,470 & 20,327 & 20,172 & 20,139 & 20,340\end{array}$

$\begin{array}{lllllll}30,681 & 30,617 & 30,625 & 30,808 & 30,849 & 30,594\end{array}$

$\begin{array}{lllllll}8,468 & 8,581 & 8,652 & 8,831 & 8,900 & 8,961\end{array}$

$\begin{array}{llllll}35,084 & 34,315 & 33,720 & 31,762 & 32,007 & 32,298\end{array}$

$\begin{array}{llllll}20,568 & 20,810 & 20,828 & 18,250 & 17,086 & 17,631\end{array}$

$\begin{array}{llllll}204,516 & 205,098 & 204,740 & 195,121 & 199,348 & 200,838\end{array}$

$\begin{array}{llllll}370.6 & 371.6 & 371.0 & 353.5 & 361.2 & 363.8 \\ 160.3 & 160.8 & 160.5 & 153.0 & 156.3 & 157.5 \\ 133.4 & 133.8 & 133.5 & 127.3 & 130.0 & 131.0 \\ 66.43 & 666.2 & 66.50 & 633.8 & 647.5 & 652.3\end{array}$


Table 13. Total Plant Investment

(Plant Investment in $10^{6}$ \$, 1994 US Gulf Coast Basis)

\begin{tabular}{lcccccc} 
Condition & $\mathbf{1}$ & $\mathbf{2}$ & $\mathbf{3}$ & $\mathbf{4}$ & $\mathbf{5}$ & $\mathbf{6}$ \\
Coal Preparation & 57.6 & 57.6 & 57.6 & 57.6 & 57.6 & 57.6 \\
Liquefaction & 664.3 & 666.2 & 665.0 & 633.8 & 647.5 & 652.3 \\
Hydrogen Manufacture & 363.5 & 355.8 & 338.9 & 287.6 & 284.7 & 327.6 \\
Oxygen Plant & 74.2 & 84.5 & 102.5 & 124.2 & 115.7 & 83.6 \\
Treating & 346.4 & 355.6 & 357.1 & 332.4 & 307.1 & 320.1 \\
Product Upgrading & 115.9 & 114.5 & 112.1 & 110.7 & 111.6 & 115.1 \\
Utilities & 318.4 & 325.1 & 337.8 & 343.1 & 330.4 & 307.1 \\
Tankage, Waste Handling & 158.0 & 149.8 & 136.1 & 121.6 & 125.9 & 147.8 \\
General Offsites & 211.0 & 211.0 & 211.0 & 211.0 & 211.0 & 211.0 \\
\hline Subtotal & $2,309.3$ & $2,320.1$ & $2,318.1$ & $2,222.0$ & 2191.5 & $2,222.2$ \\
Contingency \& Fee & 461.3 & 463.4 & 463.2 & 443.7 & 437.9 & 444.1 \\
Total Plant Investment & $2,770.6$ & $2,783.5$ & $2,781.3$ & $2,665.7$ & $2,629.4$ & $2,666.3$ \\
\$/BPSD of Product & 54,710 & 58,800 & 66,240 & 73,390 & 71,210 & 58,630
\end{tabular}


Table 14. Product Cost

Condition

Operating Costs, $10^{6} \$ / y r$

Coal, as received ( $\$ 13.25 /$ Ton)

Natural Gas (\$2.00/10 6 BTU)

River Waste $\left(\$ 0.10 / 10^{3}\right.$ gal)

Waste Disposal (\$5.00/Ton)

Catalysts \& Chemicals

Dispersed Catalyst

Labor

Maintenance

Capital-related costs

Total

By-product Credits, $10^{6} \$ / y r$

Propane (\$12.50/B)

Butane (\$14.50/B)

Sulfur (\$52.00/Ton)

Ammonia (\$120.00/Ton)

Total

Net Product cost, $10^{6} \$ /$ year

Net Product cost, \$/B

Equivalent Crude Price, \$/B
1

$\underline{2}$

3

4

5

$\underline{6}$

$\begin{array}{cccccc}58.03 & 58.03 & 58.03 & 58.03 & 58.03 & 58.03 \\ 93.01 & 83.54 & 65.48 & 41.17 & 46.49 & 79.23 \\ 0.24 & .026 & 0.27 & 0.31 & 0.28 & 0.23 \\ 0.87 & 0.87 & 0.88 & 0.90 & 1.28 & 1.26 \\ 20.03 & 17.79 & 13.73 & 7.46 & 7.90 & 15.19 \\ 33.94 & 49.11 & 33.94 & 33.94 & 33.94 & 33.94 \\ 22.99 & 22.99 & 22.99 & 22.99 & 22.99 & 22.99 \\ 20.59 & 20.59 & 20.59 & 20.59 & 20.59 & 20.59 \\ 415.41 & 415.57 & 412.65 & 393.61 & 388.82 & 398.25 \\ 665.11 & 668.75 & 628.56 & 579.00 & 580.32 & 629.71\end{array}$

$\begin{array}{cccccc}23.46 & 24.83 & 25.72 & 22.56 & 20.12 & 22.24 \\ 16.03 & 16.23 & 17.18 & 14.92 & 13.45 & 15.08 \\ 0.59 & 0.61 & 0.65 & 0.66 & 0.64 & 0.55 \\ 4.66 & 4.30 & 3.99 & 3.04 & 3.28 & 3.37 \\ 44.74 & 45.97 & 47.54 & 41.18 & 37.49 & 41.24 \\ 620.37 & 622.78 & 581.02 & 537.82 & 542.83 & 588.47 \\ 37.29 & 40.05 & 42.12 & 45.07 & 44.75 & 39.39 \\ 31.20 & 34.00 & 36.16 & 39.29 & 38.95 & 33.33\end{array}$


Table 15. Breakdown of Equivalent Crude Oil Price

Condition

Total Product, B/D

Contribution to Price, $\$ / B$

Coal
Natural Gas
River Water
Waste Disposal
Catalysts \& Chemicals
Labor
Maintenance
Capital-related costs
By-product credits
Equivalent Crude Price, \$/B

$\begin{array}{llllll}\underline{\mathbf{1}} & \underline{\mathbf{2}} & \underline{\mathbf{3}} & \underline{\mathbf{4}} & \underline{\mathbf{5}} & \underline{\mathbf{6}} \\ 50,641 & 47, \overline{3} 37 & 41,987 & 36,322 & 36,924 & 45,477\end{array}$

$\begin{array}{llllll}2.92 & 3.17 & 3.61 & 4.24 & 4.16 & 3.29\end{array}$

$\begin{array}{lllllll}4.68 & 4.56 & 4.08 & 3.01 & 3.34 & 4.49\end{array}$

$\begin{array}{lllllll}0.01 & 0.01 & 0.02 & 0.02 & 0.09 & 0.07\end{array}$

$\begin{array}{lllllll}0.04 & 0.05 & 0.06 & 0.07 & 0.09 & 0.07\end{array}$

$\begin{array}{lllllll}2.71 & 3.654 & 2.97 & 3.03 & 3.00 & 2.78\end{array}$

$\begin{array}{llllll}1.16 & 1.26 & 1.43 & 1.68 & 1.65 & 1.30\end{array}$

$\begin{array}{llllll}1.04 & 1.12 & 1.28 & 1.50 & 1.48 & 1.17\end{array}$

$\begin{array}{lllllll}20.89 & 22.69 & 25.67 & 28.75 & 27.90 & 22.56\end{array}$

$\begin{array}{llllll}-2.25 & -2.51 & -2.96 & -3.01 & -2.69 & -2.34\end{array}$

$\begin{array}{llllll}31.20 & 34.00 & 36.1 & 39.29 & 38.95 & 33.33\end{array}$ 

Figure 2

Daily Operating Conditions

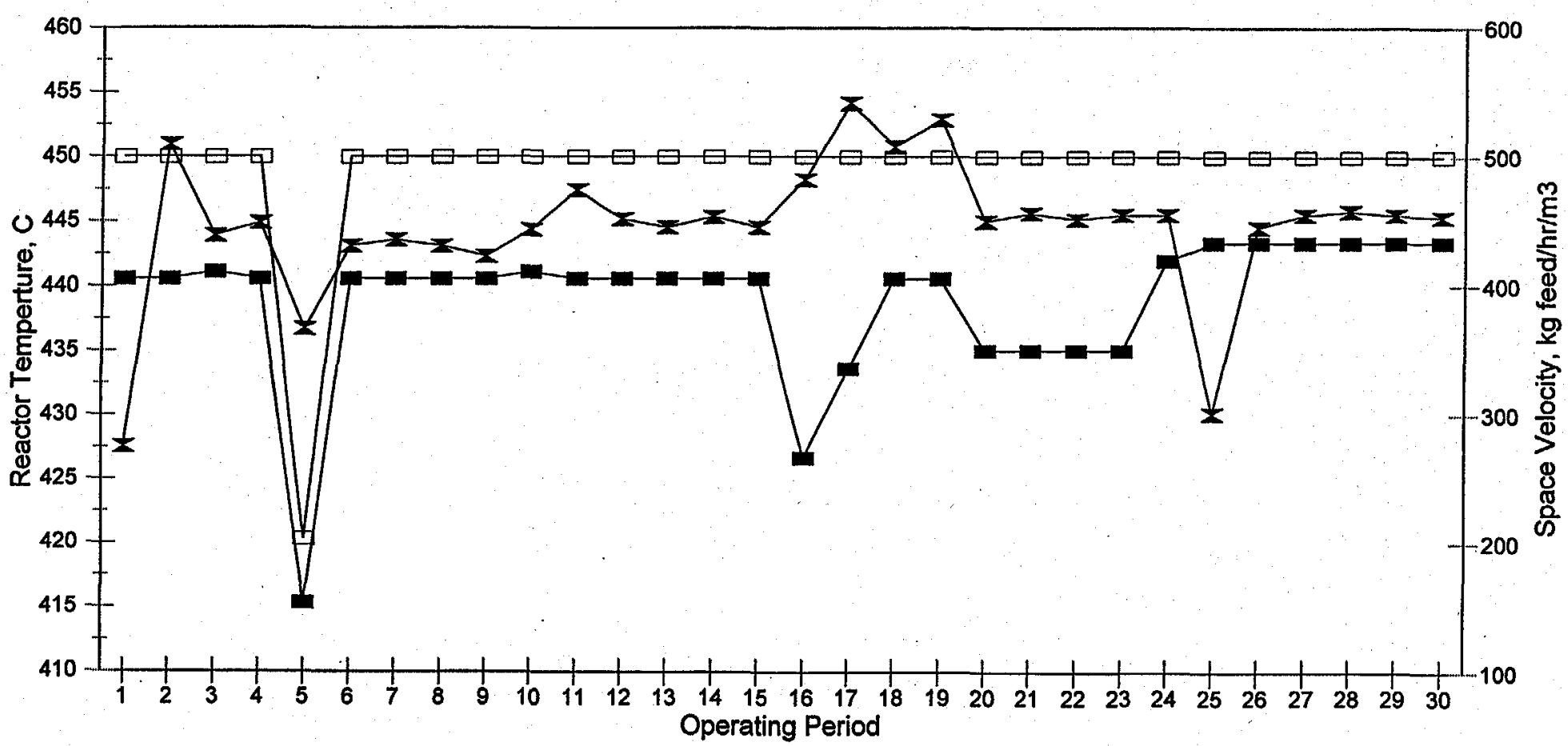

$\longrightarrow$ K-1 Temp. $\quad$ K-2 Temp. $\longrightarrow$ Space Velocity 




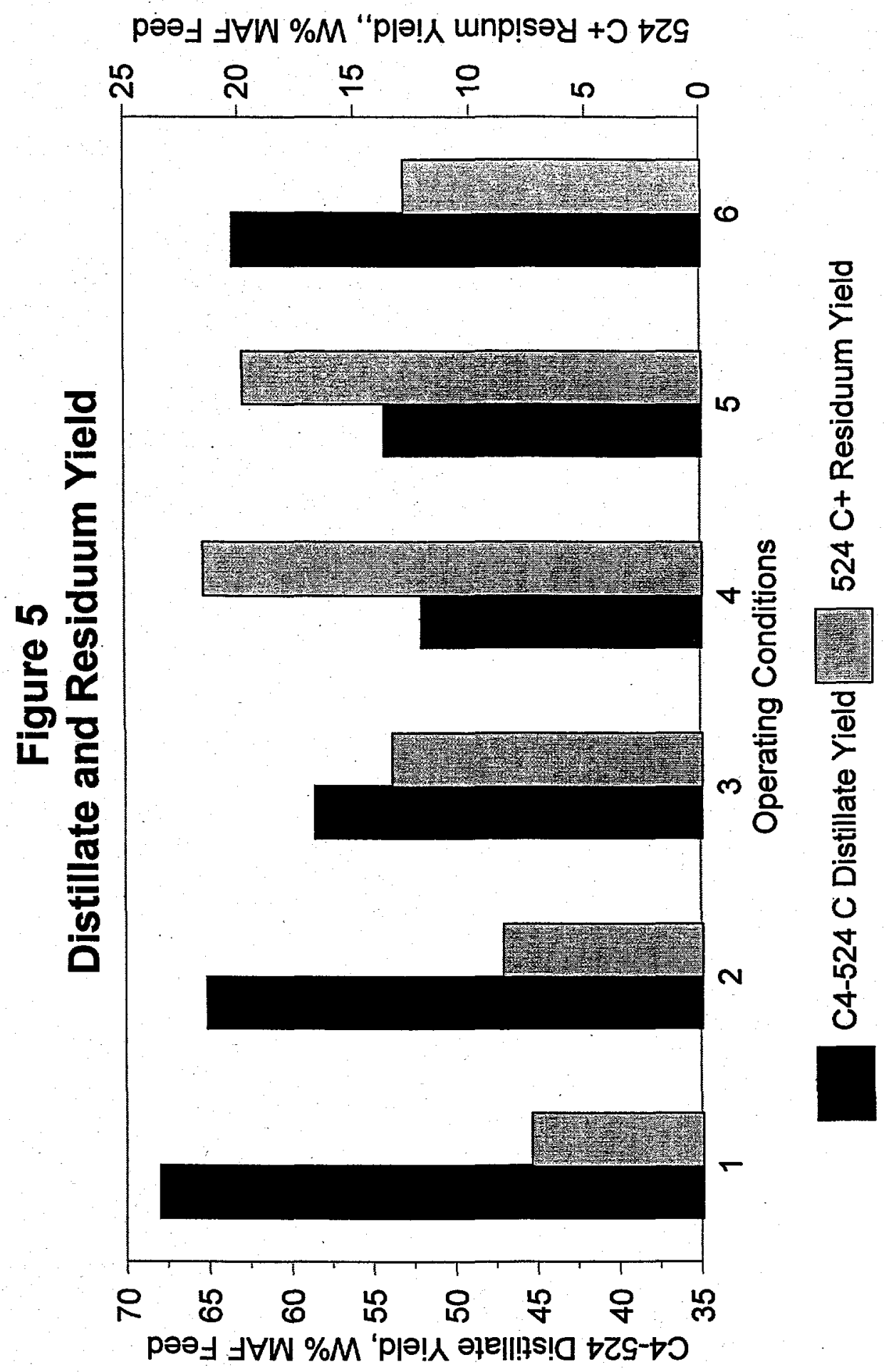




Figure 8

Hydrogen Efficiency \& Gas Selectivity

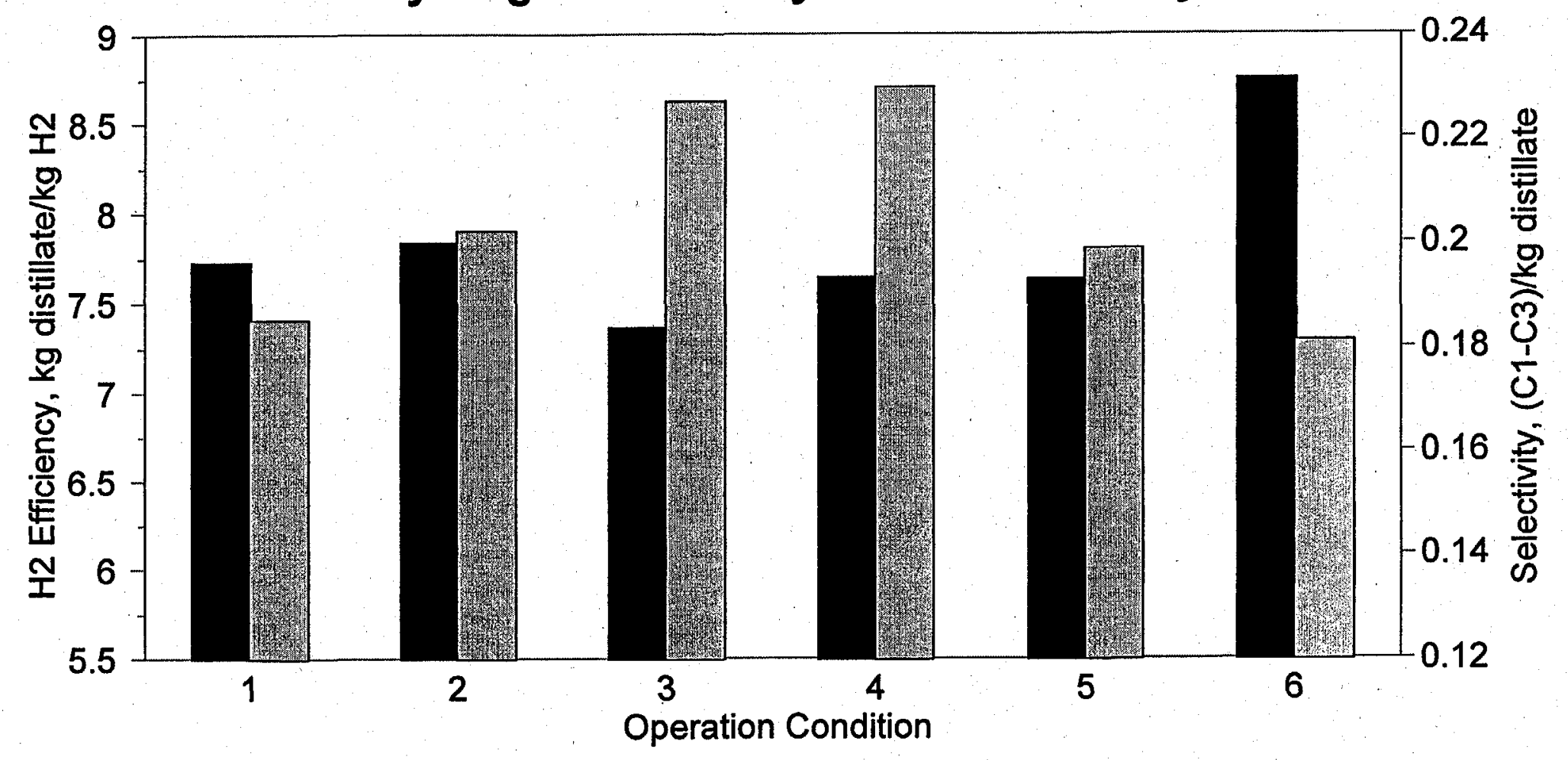

H2 Efficiency 1 C1-C3 selectivity 


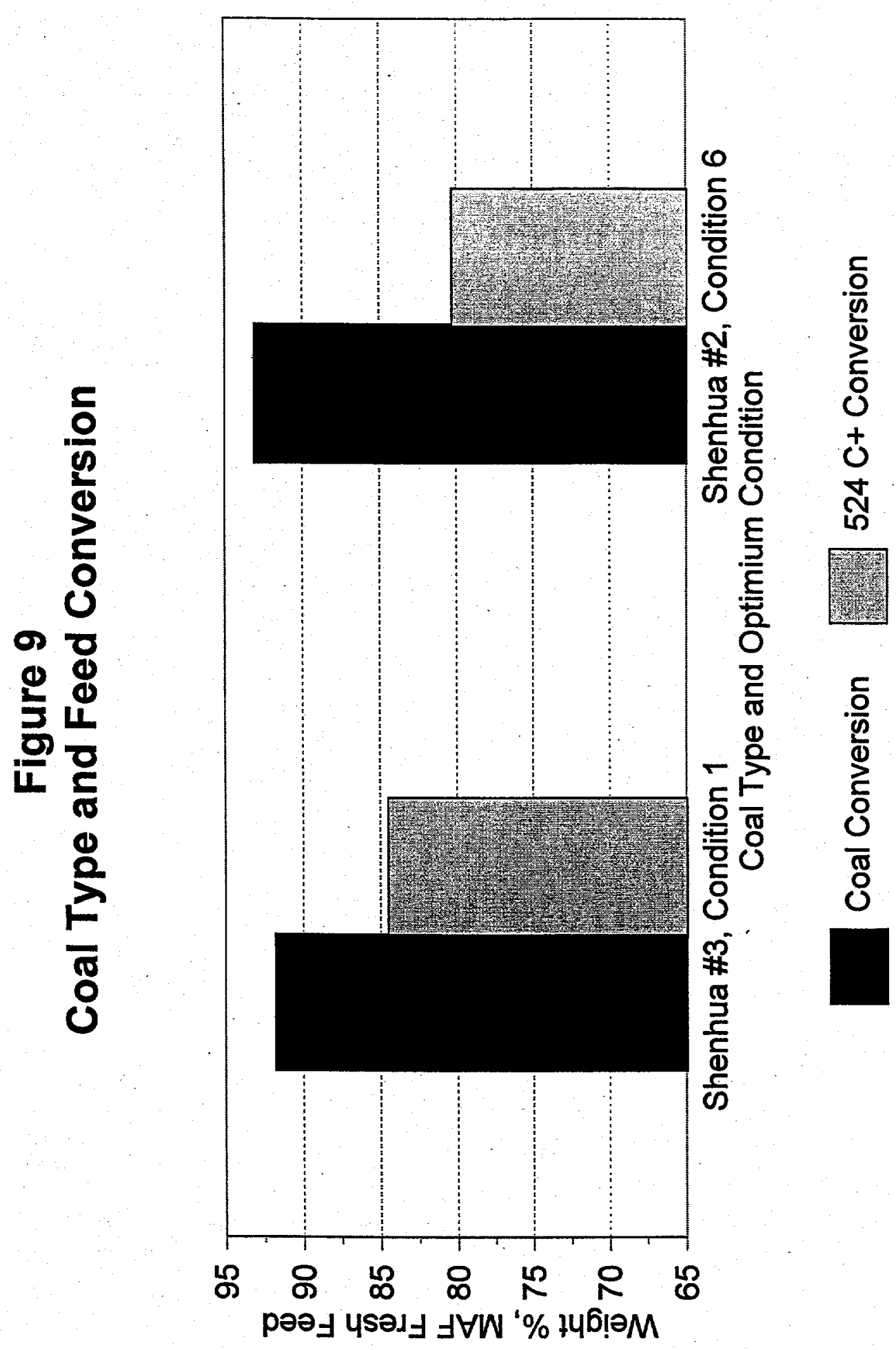




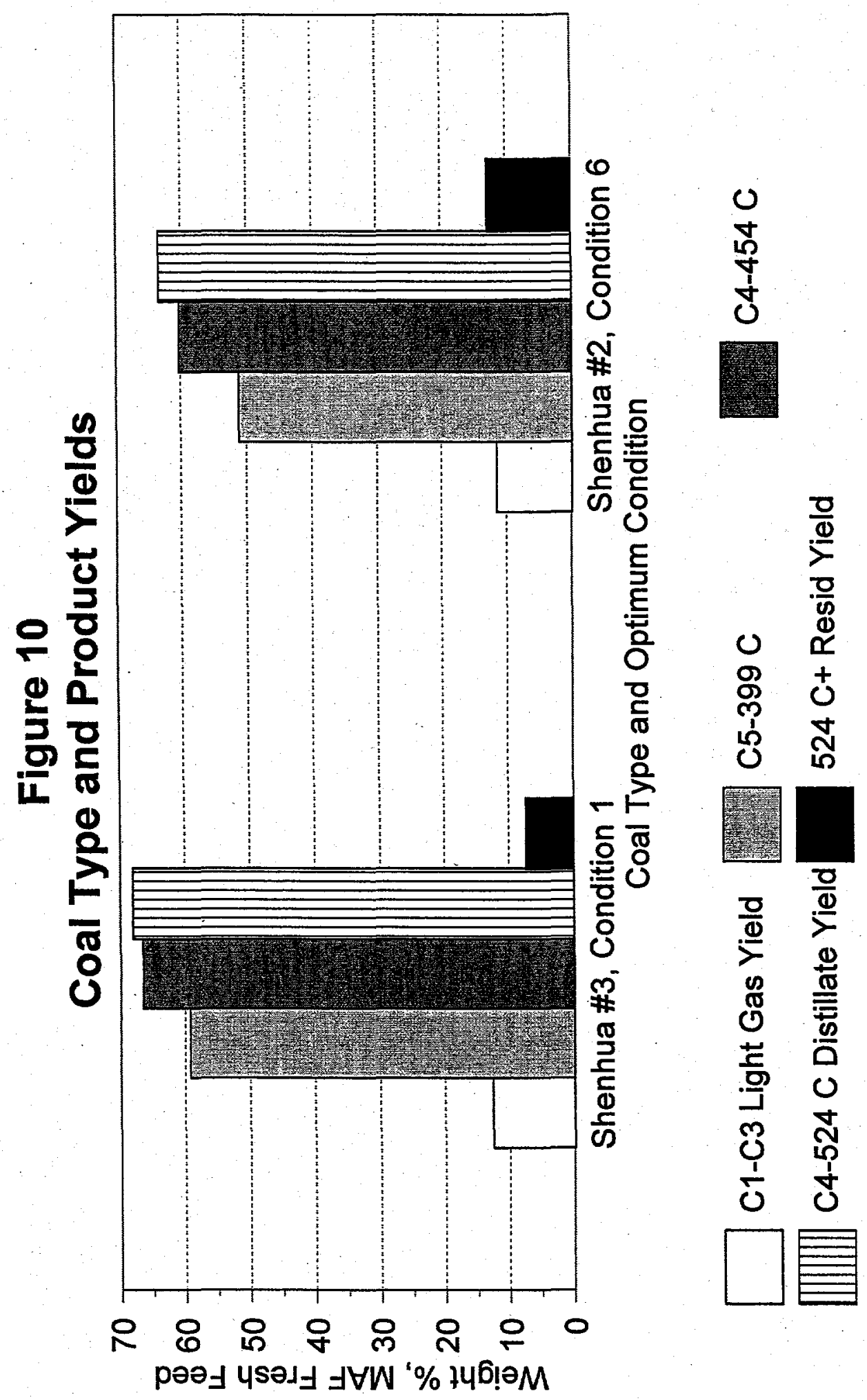




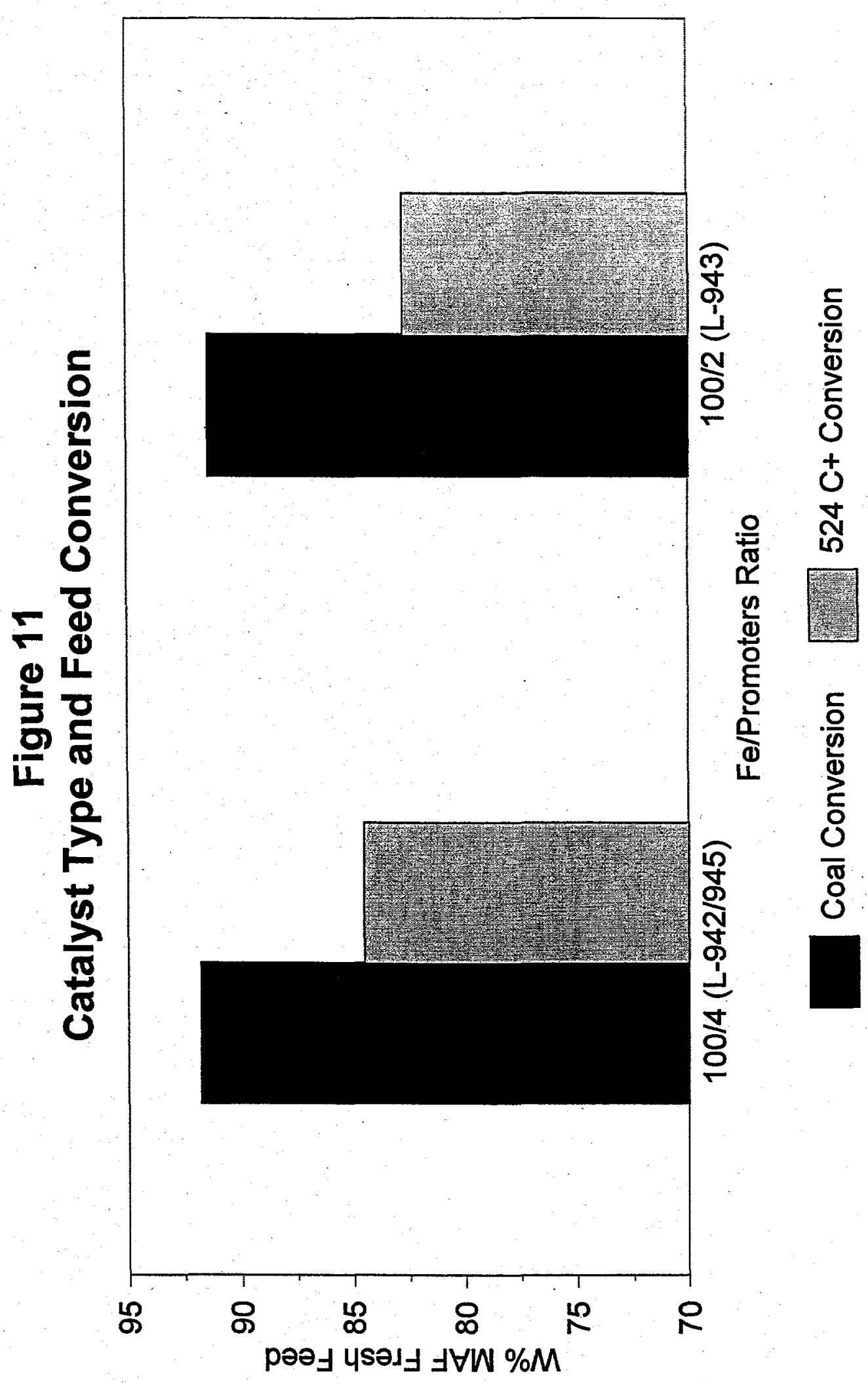




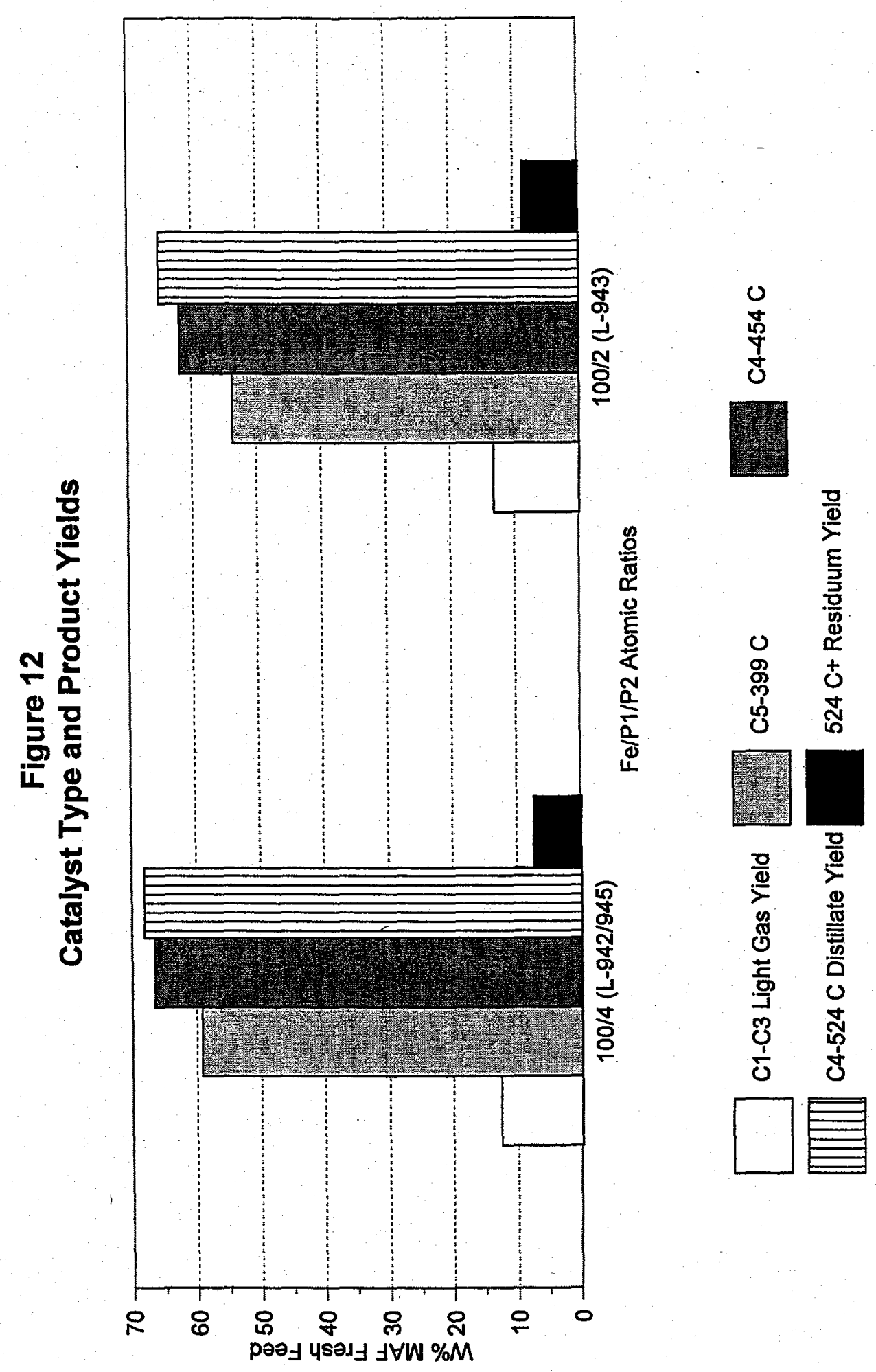




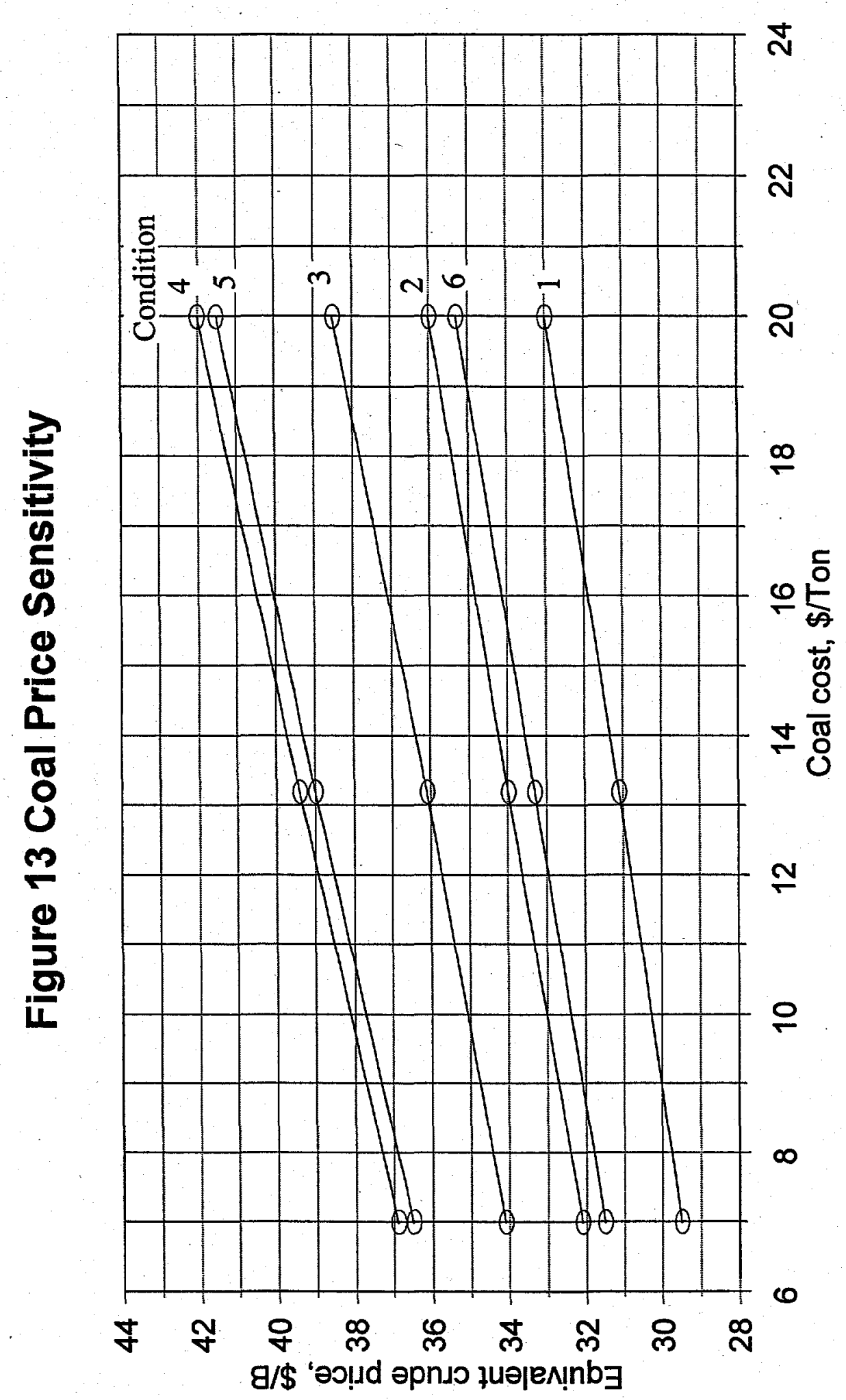




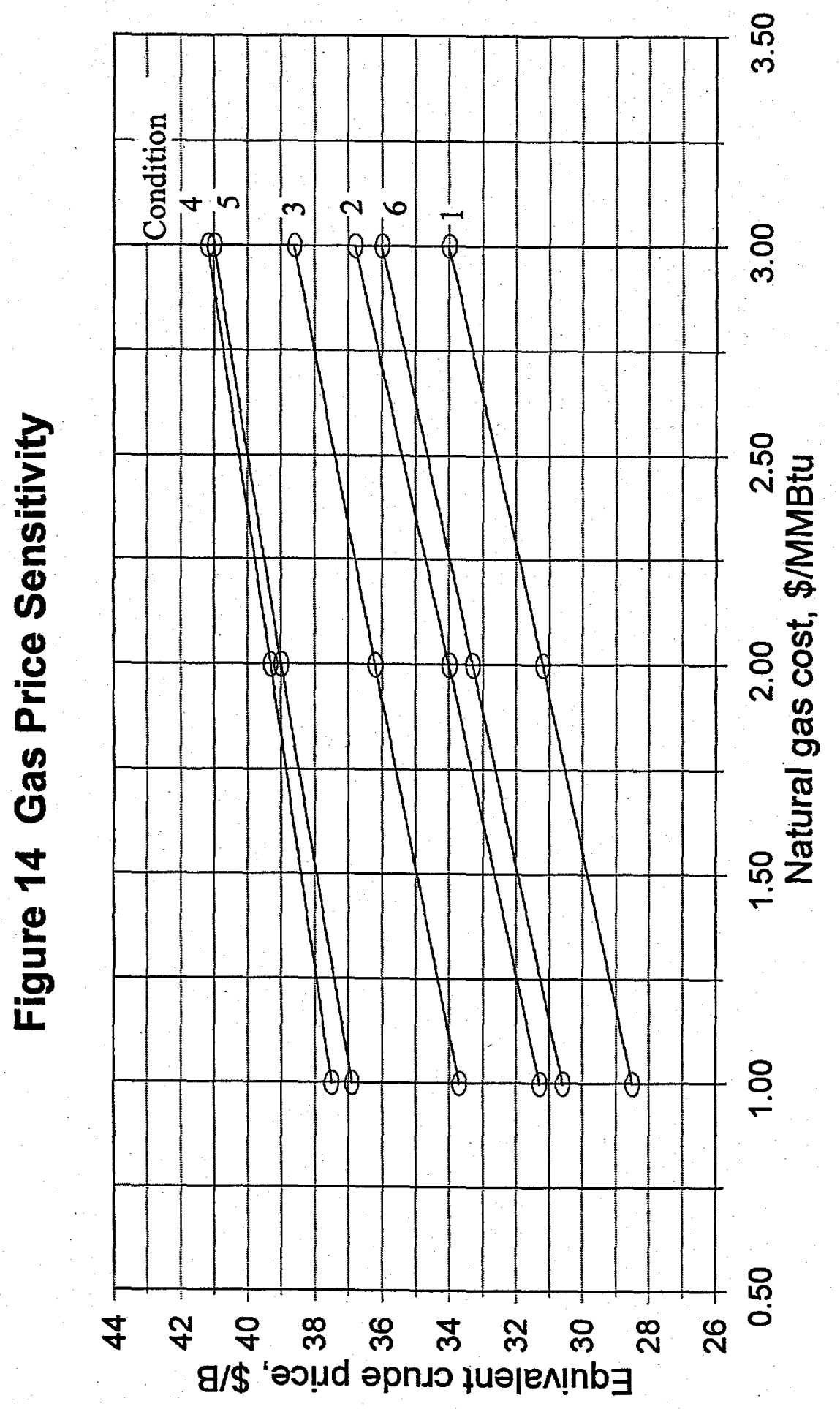

